\title{
PENGARUH PENAMBAHAN SAT ADDITIVE ADDITION H.E TERHADAP KUAT TEKAN BETON
}

\author{
Ni Ketut Sri Astati Sukawati \\ Jurusan Teknik Sipil, Fakultas Teknik, Universitas Mahasaraswati, Denpasar \\ Jl. Kamboja No.11A, Kreneng Denpasar, Bali 80233 \\ E-mail:sriastatisukawati@yahoo.com
}

\begin{abstract}
Abstrak - Beton dengan berbagai variannya menjadi kebutuhan dasar dalam membuat sebuah bangunan. Campuran betonpun beraneka ragam tegantung dari perencanaan yang dibuat sebelumnya. Campuran semen biasanya berupa campuran batu buatan, semen, air dan agregat halus serta agregat kasar. Agregat (agregat halus dan agregat kasar) berfungsi sebagai bahan pengisi dalam campuran beton. (Subakti, A.,1994). Namun dalam pembuatan bangunan sering campuran beton ditambahkan bahan (additive) namun masih ada rasa kurang yakin pada saat pembongkaran cetakan dan acuan sebelum beton mencapai kekuatan yang cukup untuk memikul berat sendiri dan beban-beban pelaksanaan yang bekerja padanya. Untuk mengatasi waktu pelaksanaan pekerjaan yang berkaitan dengan beton perlu dicarikan alternatif pemecahannya, misalnya dengan mencari bahan alternatif campuran beton atas dasar pertimbangan dengan tidak mengurangi mutu dari beton tersebut. Dari hasil penelitian sebelumnya disebutkan bahwa akibat penggantian sebagian semen dengan Fly Ash, maka kuat desak dan kuat tarik beton mengalami peningkatan (Budhi Saputro, A., 2008). Berdasarkan uraian di atas maka penulis berupaya untuk meneliti tentang seberapa kuat tekan karakteristik beton yang terjadi dengan penambahan bahan tambahan (additive) Addition H.E dalam campuran beton dan adakah pengaruh bahan tambahan (additive) Additon H.E terhadap peningkatan kuat tekan karakteristik beton tersebut. Dari hasil penelitian didapatkan bahwa kuat tekan beton dengan penambahan bahan tambahan (additive) Additon H.E adalah bahwa setelah dilaksanakan test kuat tekan kubus beton dan analisa kuat tekan beton dari 10 benda uji, dimana pada masing-masing percobaan dilaksanakan pembuatan benda uji kubus dengan penambahan Additon H.E dengan dosis 80 cc, 120 cc, dan 200 cc dapat mempercepat dan meningkatkan Kuat Tekan Karakteristik Beton.
\end{abstract}

Kata Kunci : Sat Aditive, Kuat Tekan, Beton

\begin{abstract}
Concrete with various variants is a basic requirement in building a building. The concrete mixture is diverse depending on the planning made beforehand. The cement mixture is usually in the form of a mixture of artificial stone, cement, water and fine aggregates and coarse aggregates. Aggregates (fine aggregates and coarse aggregates) function as fillers in concrete mixtures. (Subakti, A., 1994). However, in building construction, additives are often added, but there is still a sense of uncertainty at the time of dismantling the mold and the reference before the concrete reaches sufficient strength to carry its own weight and the carrying loads acting on it. To overcome the time of carrying out work related to concrete, it is necessary to find an alternative solution, for example by looking for alternative ingredients of concrete mixture on the basis of consideration without reducing the quality of the concrete. From the results of previous studies it was stated that due to the partial replacement of cement with Fly Ash, the strength of the pressure and tensile strength of the concrete had increased (Budhi Saputro, A., 2008). Based on the description above, the author seeks to examine how the compressive strength of concrete characteristics that occur by adding additives Addition H.E in the concrete mixture and is there any additive Additon H.E effect on the increase in the compressive strength characteristic of the concrete. From the results of the study, it was found that the compressive strength of the concrete with the addition of additives HE was that after the compressive strength test of the concrete cube was carried out and the analysis of concrete compressive strength of 10 specimens, in each experiment a cube specimen was made with the addition of additons. HE with a dose of 80 cc, 120 cc, and $200 \mathrm{cc}$ can accelerate and increase the compressive strength of concrete characteristics.
\end{abstract}

Keywords: Additive, Compressive Strength, Concrete

\section{Pendahuluan}

1.1. Latar Belakang

Beton merupakan batu buatan yang dibuat dari campuran semen, air dan agregat halus serta agregat kasar. Agregat (agregat halus dan agregat kasar) berfungsi sebagai bahan pengisi dalam campuran beton. (Subakti, A.,1994).

Pembuatan bangunan di lapangan yang berkaitan dengan beton sering ditambahkan 
bahan (additive) namun masih ada rasa kurang yakin pada saat pembongkaran cetakan dan acuan sebelum beton mencapai kekuatan yang cukup untuk memikul berat sendiri dan bebanbeban pelaksanaan yang bekerja padanya. Untuk mengatasi waktu pelaksanaan pekerjaan yang berkaitan dengan beton perlu dicarikan alternatif pemecahannya, misalnya dengan mencari bahan alternatif campuran beton atas dasar pertimbangan dengan tidak mengurangi mutu dari beton tersebut. Dari hasil penelitian sebelumnya disebutkan bahwa akibat penggantian sebagian semen dengan Fly Ash, maka kuat desak dan kuat tarik beton mengalami peningkatan (Budhi Saputro, A., 2008).

Dalam Peraturan Beton Bertulang Indonesia 1971 disebutkan bahwa untuk memperbaiki mutu beton, sifat-sifat pengerjaan, waktu pengikatan dan pengerasan ataupun untuk maksud-maksud lain, dapat dipakai bahan-bahan pembantu. Pemakaian bahan-bahan pembantu harus dapat dibuktikan dengan hasil-hasil percobaan.

\subsection{Rumusan Masalah}

Berdasarkan uraian latar belakang di atas maka rumusan masalah yang akan ditelaah dalam penelitian ini adalah berapa kuat tekan karakteristik beton yang terjadi dengan penambahan bahan tambahan (additive) Addition H.E dalam campuran beton dan adakah pengaruh bahan tambahan (additive) Additon H.E terhadap peningkatan kuat tekan karakteristik beton?

\section{Tinjauan Pustaka}

\subsection{Pengertian Beton}

Beton merupakan fungsi dari bahan penyusunan yang terdiri dari bahan semen hydrolik (portland cement), agregat kasar, agregat halus dan air juga dapat ditambahkan zat addictive dengan campuran tertentu yang kemudian akan mengering, mengeras dan mempunyai bentuk sesuai dengan acuan / cetakan yang dibentuk. (Mulyono, T., 2003).

Dalam Peraturan Beton Bertulang Indonesia 1971, beton didefinisikan sebagai suatu bahan konstruksi yang mempunyai sifat kekuatan tekan yang khas, yaitu apabila diperiksa dengan sejumlah besar benda-benda uji, nilainya akan menyebar sekitar suatu nilai rata-rata tertentu. Penyebaran dari hasil-hasil pemeriksaan ini akan kecil atau besar tergantung pada tingkat kesempurnaan dari pelaksanaanya.

\subsection{Sifat - Sifat Beton}

Pada umumnya beton memiliki sifat kuat menerima gaya tekan tetapi kurang mampu menerima gaya tarik, sehingga untuk mengatasi hal tersebut dipakailah tulangan untuk memikul gaya tarik yang terjadi apabila beton menerima gaya tarik. Di samping sifat tekan dan tarik, beton juga memiliki sifat awet dan kedap air yang dapat diandalkan. Selain itu sifat-sifat beton lain adalah susut, rangkak dan retak beton.

\section{Pembahasan}

\subsection{Analisis Bahan-Bahan Beton}

Hasil analisis bahan yang diperoleh dari percobaan di laboratorium harus sesuai dengan syarat-syarat material pembentuk beton yang ditentukan dalam pedoman pengerjaan beton. Data ini selanjutnya akan dipakai dalam menghitung Mix Design campuran beton.

\subsubsection{Agregat Halus ( Pasir )}

Dari hasil pemeriksaan pasir di laboratorium di dapat data pasir sebagai berikut :

1. Berat jenis (Spesifik gravity) pasir Klungkung dalam keadaan SSD $=2,444 \mathrm{gr}$ dan penyerapan air pasir klungkung $=1.978 \%$ dapat dilihat pada tabel 3.1

Tabel 3.1 Pemeriksaan Berat Jenis Dan

\begin{tabular}{|l|l|l|}
\cline { 2 - 3 } NO & \multicolumn{1}{|c|}{ URAIAN } & KETERANGAN \\
\hline 1 & $\begin{array}{l}\text { Berat Pasir SSD (Bj) } \\
\text { Berat picnometer + Air (Ba) }\end{array}$ & $500,00 \mathrm{gram}$ \\
$629,00 \mathrm{gram}$ \\
3 & $\begin{array}{l}\text { B. picnometer + Pasir SSD } \\
\text { +Air (Bt) } \\
\text { Berat Pasir Kering oven (Bk) }\end{array}$ & $924,40 \mathrm{gram}$ \\
4 & $\begin{array}{l}\text { Berat jenis Bulk }= \\
5\end{array}$ & $2,30 \mathrm{gram}$ \\
6 & $\begin{array}{l}B a+B j-B t \\
\text { Berat jenis SSD }\end{array}$ & Kg/lt \\
7 & $\frac{B j}{B a+B j-B t}$ & $2,444 \mathrm{Kg} / \mathrm{lt}$ \\
\hline
\end{tabular}

Penyerapan Air Dalam Pasir 
Sumber : Hasil Pemeriksaan Bahan di Laboratorium

2. Gradasi agregat halus (pasir) Klungkung dengan modulus kehalusan $(\mathrm{Fm})=2,71$ dapat dilihat pada table 4.2. Nilai ini memenuhi syarat menurut British Standar (BS) yaitu modulus kehalusan untuk pasir berkisar antara $1,5-3,8$.

Tabel 3.2 Pemeriksaan Gradasi pasir

\begin{tabular}{|c|c|c|c|c|c|c|c|}
\hline \multicolumn{2}{|c|}{ Ayakan } & \multicolumn{3}{|c|}{ Percobaan } & \multirow[b]{2}{*}{ (\%) } & \multirow{2}{*}{$\begin{array}{c}\text { Jumlah } \\
\text { diatas } \\
\text { ayakan }\end{array}$} & \multirow{2}{*}{$\begin{array}{c}\text { Jumla } \\
\text { h yang } \\
\text { lolos }\end{array}$} \\
\hline NO & $\begin{array}{c}\varnothing \\
(\mathrm{mm})\end{array}$ & I & II & $\begin{array}{l}\text { Jum } \\
\text {-lah }\end{array}$ & & & \\
\hline $3 / 8 "$ & 10 & 0 & 0 & 0 & 0 & 0 & 100 \\
\hline $3 / 16^{\prime \prime}$ & 5 & 0 & 0 & 0 & 0 & 0 & 100 \\
\hline .7 & 2,36 & $\begin{array}{c}162 \\
1\end{array}$ & $\begin{array}{c}157 \\
2\end{array}$ & $\begin{array}{c}319, \\
3\end{array}$ & $\begin{array}{c}15,9 \\
65\end{array}$ & 15,965 & 84,035 \\
\hline .14 & 1,18 & $\begin{array}{c}167 \\
2\end{array}$ & $\begin{array}{c}159 \\
6\end{array}$ & $\begin{array}{c}326, \\
8\end{array}$ & $\begin{array}{c}16,3 \\
40\end{array}$ & 32,305 & 67,695 \\
\hline .25 & 600 & $\begin{array}{c}178 \\
2\end{array}$ & $\begin{array}{c}191 \\
4\end{array}$ & $\begin{array}{c}369 \\
7\end{array}$ & $\begin{array}{c}18,4 \\
85\end{array}$ & 50,79 & 49,21 \\
\hline .52 & 300 & $\begin{array}{c}251 \\
5\end{array}$ & $\begin{array}{c}264 \\
3\end{array}$ & $\begin{array}{c}515 \\
8\end{array}$ & $\begin{array}{c}25,7 \\
9\end{array}$ & 76,58 & 23,42 \\
\hline .100 & 150 & $\begin{array}{c}196, \\
2\end{array}$ & $\begin{array}{c}183 \\
9\end{array}$ & $\begin{array}{c}380, \\
1\end{array}$ & $\begin{array}{c}19,0 \\
05\end{array}$ & 95,585 & 4,415 \\
\hline Pan & & 44,7 & 43,6 & 88,3 & $\begin{array}{c}4,41 \\
5\end{array}$ & 100 & 0 \\
\hline
\end{tabular}

Sumber : Hasil Pemeriksaan Bahan di Laboratorium

$\mathrm{FM}=$

$$
\begin{aligned}
& \frac{15,965+32,305+50,79+76,58+95,585}{100} \\
& =2,71
\end{aligned}
$$

3. adar lumpur (Mud Content) pasir Klungkung = $1,0 \%$. Berarti pasir mememuhi syarat untuk campuran beton sesuai yang disyaratkan dalam PBI 71 bahwa agregat halus untuk campuran beton tidak boleh mengandung

\begin{tabular}{|c|l|c|}
\hline NO & \multicolumn{1}{|c|}{ URAIAN } & KETERANGAN \\
\hline 1 & $\begin{array}{l}\text { Berat Pasir kering } \\
\text { oven (VI) }\end{array}$ & 1000 gram \\
\hline 2 & $\begin{array}{l}\text { Berat pasir setelah } \\
\text { dicuci dan dioven (V2) }\end{array}$ & 990 gram \\
\hline 3 & $\begin{array}{l}\text { Kadar Lumpur }= \\
\frac{V 1-V 2}{V 1} x 100 \%\end{array}$ \\
\hline
\end{tabular}

lumpur lebih dari $5 \%$ terhadap berat kering.

Tabel 3.3 Pemeriksaan Kadar Lumpur

Sumber : Hasil Pemeriksaan Bahan di Laboratorium

4. Berat satuan (Unit Weight) pasir Klungkung $=$

\begin{tabular}{|c|c|c|c|}
\hline \multirow{2}{*}{ No } & \multirow{2}{*}{ URAIAN } & \multicolumn{2}{|c|}{ KETERANGAN } \\
\hline & & RODDING & SOVELING \\
\hline 1 & Berat kotak takar & $2164 \mathrm{gr}$ & $2164 \mathrm{gr}$ \\
\hline 2 & Berat Kotak takar + air & $4094 \mathrm{gr}$ & $4094 \mathrm{gr}$ \\
\hline 3 & Berat Air & $1930 \mathrm{gr}$ & $1930 \mathrm{gr}$ \\
\hline 4 & $\begin{array}{l}\text { Volume kotak takar }= \\
\frac{\text { Berat Air }}{1000}\end{array}$ & $1,93 \mathrm{lt}$ & 1,93 lt \\
\hline 5 & Berat kotak takar + pasir & $4997,71 \mathrm{gr}$ & $4736,71 \mathrm{gr}$ \\
\hline 6 & Berat Pasir & $2833,71 \mathrm{gr}$ & $2572,71 \mathrm{gr}$ \\
\hline 7 & $\begin{array}{l}\text { Berat Satuan }= \\
\text { Berat pasir }\end{array}$ & $1468,24 \mathrm{gr}$ & $1333,01 \mathrm{gr}$ \\
\hline & Vol Kotak takar & & \\
\hline 8 & Rata-rata & & $\mathrm{gr} / \mathrm{tt}$ \\
\hline
\end{tabular}
$1,40 \mathrm{Kg} / \mathrm{lt}$ dapat dilihat pada table 4.4 .

Tabel 3.4 Pemeriksaan Berat Satuan Pasir

Sumber : Hasil Pemeriksaan Bahan di Laboratorium 
Tabel 3.6 Pemeriksaan Gradasi Agregat Kasar

5. Kadar air (Surface Moisture) pasir Klungkung $=5,11 \%$ dapat dilihat pada table 3.5

Tabel 3.5 Pemeriksaan Kadar Air

\begin{tabular}{|c|l|c|}
\hline No. & \multicolumn{1}{|c|}{ URAIAN } & KETERANGAN \\
\hline 1 & Berat cawan kosong (W1) & 55 gram \\
3 & $\begin{array}{l}\text { Berat cawan + Pasir } \\
\text { sesungguhnya (W2) }\end{array}$ & 909,0 gram \\
4 & $\begin{array}{l}\text { Berat cawan + Pasir kering } \\
\text { Berat air (W2 }-\mathrm{W} 3)\end{array}$ & 867,5 gram \\
5 & $\begin{array}{l}\text { Berat pasir kering }(\mathrm{W} 3-\mathrm{W} 1) \\
6\end{array}$ & $\begin{array}{l}\text { Kadar air }=\frac{(w 2-w 3)}{(w 3-w 1)} \times \\
(100 \%\end{array}$
\end{tabular}

Sumber : Hasil Pemeriksaan Bahan di Laboratorium

\subsubsection{Agregat Kasar (Koral)}

Dari pemerikasaan agregat kasar (koral) pada percobaan pendahuluan di laboratorium didapat data mengenai Koral sebagai berikut:

1. Gradasi agregat kasar (koral) didapat modulus kehalusan $(\mathrm{fm})=7,02$ dapat dilihat pada tabel 4.6 memenuhi syarat British Standar yaitu modulus kehalusan agregat kasar antara 5-8.

\begin{tabular}{|c|c|c|c|c|c|c|c|}
\hline \multicolumn{2}{|c|}{ Ayakan } & \multicolumn{3}{|c|}{ Percobaan } & \multirow[b]{2}{*}{$(\%)$} & \multirow{2}{*}{$\begin{array}{c}\text { Jum- } \\
\text { lah di } \\
\text { atas } \\
\text { ayaka } \\
\text { n }\end{array}$} & \multirow{2}{*}{$\begin{array}{c}\text { Jum- } \\
\text { lah } \\
\text { yang } \\
\text { lolos }\end{array}$} \\
\hline NO & $\begin{array}{c}\varnothing \\
(\mathrm{mm} \\
)\end{array}$ & I & II & $\begin{array}{c}\text { Jum- } \\
\text { lah }\end{array}$ & & & \\
\hline $3 / 2 "$ & $\begin{array}{r}37 \\
, 5\end{array}$ & 22 & 38 & 60 & 1,20 & 1,2 & 98,8 \\
\hline $3 / 4 "$ & 20 & 952 & 1013 & 1965 & 39,20 & 40,5 & 59,5 \\
\hline $3 / 8 "$ & 10 & 751 & 712 & 1463 & 29,26 & 69,76 & 30,24 \\
\hline $\begin{array}{l}3 / 16 \\
"\end{array}$ & 5 & 660 & 672 & 1332 & 26,64 & 90,4 & 9,6 \\
\hline 7 & $\begin{array}{l}2, \\
36\end{array}$ & 115 & 65 & 180 & 3,60 & 100 & 0 \\
\hline Pan & & & & & & & \\
\hline
\end{tabular}

Sumber : Hasil Pemeriksaan Bahan di aboratorium

$$
\begin{aligned}
\mathrm{FM} & =\frac{1,2+40,5+69,76+90,4+100+400}{100} \\
& =7,02
\end{aligned}
$$

2. Berat jenis (Specifik gravity) koral dalam keadaan $S S D=2,483$ gram penyerapan airnya (water absorbtion) $=2,976 \%$. Dapat dilihat pada tabel 3.7 sebagai berikut.

Tabel 3.7 Pemeriksaan Berat Jenis Dan Penyerapan Air

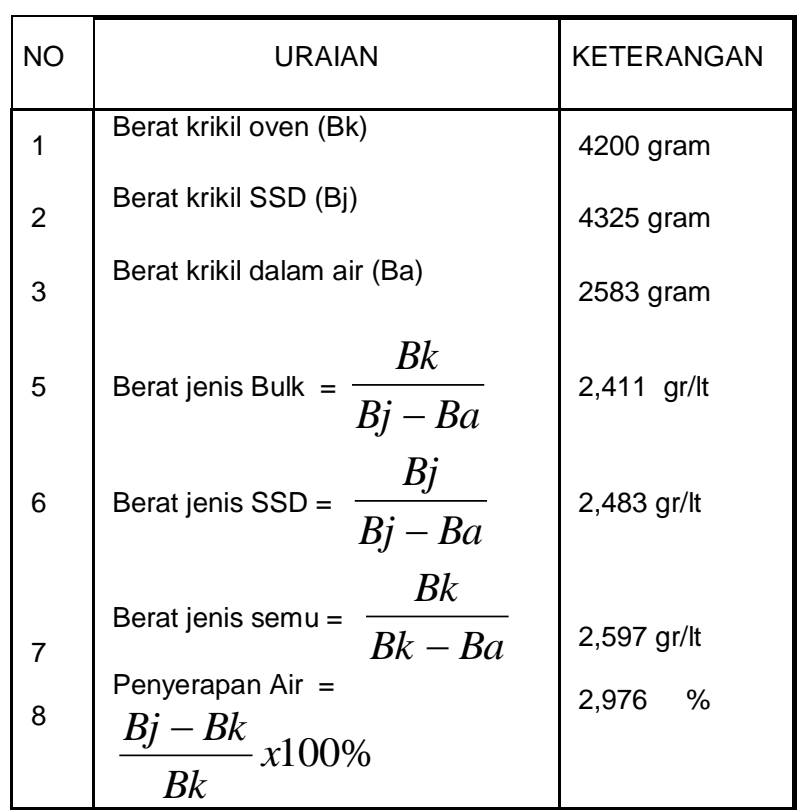


Sumber : Hasil Pemeriksaan Bahan di Laboratorium

3. Berat satuan (unit weight) koral dari pemeriksaan di dapat $1,517 \mathrm{Kg} / \mathrm{lt}$ dapat dilihat pada tabel 3.8 sebagai berikut.

Tabel 3.8 Pemeriksaan Berat Satuan Agregat Kasar

\begin{tabular}{|c|c|c|c|}
\hline \multirow{2}{*}{ No } & \multirow{2}{*}{ URAIAN } & \multicolumn{2}{|c|}{ KETERANGAN } \\
\hline & & RODDING & SOVELING \\
\hline 1 & Berat kotak takar & $6295 \mathrm{gr}$ & $6295 \mathrm{gr}$ \\
\hline 2 & Berat Kotak takar + air & $13416 \mathrm{gr}$ & $13416 \mathrm{gr}$ \\
\hline 3 & Berat Air & $7121 \mathrm{gr}$ & $7121 \mathrm{gr}$ \\
\hline 4 & $\begin{array}{l}\text { Volume kotak takar }= \\
\frac{\text { Berat Air }}{1000}\end{array}$ & $7,121 \mathrm{It}$ & $7,121 \mathrm{It}$ \\
\hline 5 & $\begin{array}{l}\text { Berat kotak takar + } \\
\text { Batu pecah }\end{array}$ & $17450 \mathrm{gr}$ & $16745 \mathrm{gr}$ \\
\hline 6 & Berat batu pecah & $11156 \mathrm{gr}$ & $10450 \mathrm{gr}$ \\
\hline 7 & $\begin{array}{l}\text { Berat Satuan }= \\
\frac{\text { Berat batu pecah }}{\text { Vol Kotak takar }}\end{array}$ & $1566,53 \mathrm{gr}$ & $1467,49 \mathrm{gr}$ \\
\hline 8 & Rata-rata & \multicolumn{2}{|c|}{$1517,49 \mathrm{gr} / \mathrm{lt}$} \\
\hline
\end{tabular}

Sumber : Hasil Pemeriksaan Bahan di Laboratorium

4. Kadar lumpur (mud content) Koral dari hasil pemeriksaan didapat $=0,41 \%$ dapat dilihat pada tabel 3.9. Nilai ini menunjukkan bahwa Koral tersebut sudah memenuhi syarat untuk campuran beton, karena agregat kasar untuk campuran beton yang disyaratkan dalam PBI 71 adalah tidak boleh mengandung lumpur lebih dari $1 \%$ terhadap berat kering.
Tabel 3.9 Pemeriksaan Kadar Lumpur

\begin{tabular}{|c|l|c|}
\hline NO & \multicolumn{1}{|c|}{ URAIAN } & KETERANGAN \\
\hline 1 & $\begin{array}{l}\text { Berat batu pecah kering } \\
\text { oven (VI) }\end{array}$ & 1000 gram \\
\hline 2 & $\begin{array}{l}\text { Berat batu pecah setelah } \\
\text { dicuci dan dioven (V2) }\end{array}$ & $999,59 \mathrm{gram}$ \\
\hline 3 & $\begin{array}{l}\text { Kadar Lumpur }= \\
\frac{V 1-V 2}{V 1} \times 100 \%\end{array}$ & $0,41 \%$ \\
\hline
\end{tabular}

Sumber : Hasil Pemeriksaan Bahan di Laboratorium

5. Kadar air (surface moisture) koral ini dari hasil pemeriksaan di laboratorium didapat 2,08 \% dapat dilihat pada tabel 3.10 sebagai berikut.

Tabel 3.10 Pemeriksaan Kadar Air

\begin{tabular}{|c|l|c|}
\hline No & \multicolumn{1}{|c|}{ URAIAN } & KETERRANAGN \\
\hline 1 & $\begin{array}{l}\text { Berat cawan kosong (W1) } \\
\text { Berat cawan + Batu } \\
\text { pecah sesungguhnya } \\
\text { (W2) }\end{array}$ & 1023,70 gram \\
3 & $\begin{array}{l}\text { Berat cawan + Batu } \\
\text { Pecah kering Oven (W3) }\end{array}$ & 1004,00 gram \\
4 & $\begin{array}{l}\text { Berat air (W2 - W3) } \\
\text { Berat Batu pecah kering } \\
\text { (W3 - W1) }\end{array}$ & 948,00 gram \\
6 & $\begin{array}{l}\text { Kadar air }=\frac{(w 2-w 3)}{(w 3-w 1)} \times \\
100 \%\end{array}$ \\
\hline
\end{tabular}




\subsubsection{Semen}

Karena semen merupakan hasil buatan pabrik, dimana dalam proses pembuatannya sudah mendapat pengawasan yang ketat sehingga dalam penelitian ini tidak dilaksanakan pemeriksaan yang khusus. Dengan anggapan bahwa semua semen Portland yang diproduksi di Indonesia bermutu baik.

Tetapi yang perlu diperhatikan sebelum semen Portland dipakai untuk campuran beton adalah bentuk butiran dari semen yang dapat diteliti secara visual, sehingga dapat diketahui apakah butiran semen mengalami penggumpalan atau tidak. Bila semen menggumpal maka semen tersebut tidak boleh dipakai untuk campuran beton. Pada penelitian ini pemeriksaan terhadap semen hanya dilakukan pemeriksaan terhadap berat satuannya saja. Dari hasil pemeriksaan semen type 1 merek Gresik didapat berat satuannya $=1,223 \mathrm{~kg} / \mathrm{lt}$.

Tabel 3.11 Pemeriksaan Berat Satuan Semen

\begin{tabular}{|c|c|c|c|}
\hline \multirow[b]{2}{*}{$\mathrm{No}$} & \multirow[b]{2}{*}{ URAIAN } & \multicolumn{2}{|c|}{ KETERANGAN } \\
\hline & & $\begin{array}{l}\text { RODDIN } \\
\text { G }\end{array}$ & SOVELING \\
\hline 1 & Berat kotak takar & $2164 \mathrm{gr}$ & $2164 \mathrm{gr}$ \\
\hline 2 & $\begin{array}{l}\text { Berat Kotak takar + } \\
\text { air }\end{array}$ & $4094 \mathrm{gr}$ & $4094 \mathrm{gr}$ \\
\hline 3 & $\begin{array}{l}\text { Berat Air } \\
\text { Volume kotak takar }\end{array}$ & $1930 \mathrm{gr}$ & $1930 \mathrm{gr}$ \\
\hline 4 & $=\frac{\text { Berat Air }}{1000}$ & $1,93 \mathrm{lt}$ & $1,93 \mathrm{lt}$ \\
\hline 5 & $\begin{array}{l}\text { Berat kotak takar + } \\
\text { Semen }\end{array}$ & $4663 \mathrm{gr}$ & 42 \\
\hline 6 & $\begin{array}{l}\text { Berat semen } \\
\text { Berat Satuan = }\end{array}$ & $2499 \mathrm{gr}$ & $2220 \mathrm{gr}$ \\
\hline 7 & Berat Semen & $\begin{array}{l}1294,8 \\
\mathrm{gr}\end{array}$ & $1150 \mathrm{gr}$ \\
\hline & $\begin{array}{l}\text { Vol Kotak takar } \\
\text { Rata-rata }\end{array}$ & & $5 \mathrm{ar} / 1$ \\
\hline
\end{tabular}

Sumber : Hasil Pemeriksaan Bahan di Laboratorium

\subsection{Rancangan Campuran Beton (Concrete Mix Design)}

Setelah dilakukan pemeriksaan bahanbahan beton maka selanjutnya dilakukan rancangan campuran beton. Dalam membuat rancangan campuran beton pada penelitian ini dipakai cara SK SNI-T-15-1990-03 "Tata Cara Pembuatan Rencana Campuran Beton Normal" atau cara "DOE / Current British Method"

\subsubsection{Ketentuan-Ketentuan Campuran Beton}

Sebelum dilaksanakan campuran beton maka perlu diketahui ketentuan-ketentuan yang dipakai dalam pertimbangan dalam membuat rencana campuran beton atau mix design, dalam penelitian ini ketentuan-ketentuan yang dipakai adalah sebagai berikut:

1. Kuat tekan beton karakteristik yang dikehendaki adalah $225 \mathrm{Kg} / \mathrm{cm}^{2}$, untuk umur beton 28 hari dengan jumlah yang mungkin tidak memenuhi syarat terbatas sampai $5 \%$.

2. Semen yang dipakai adalah semen type 1 .

3. Beton yang direncanakan tidak terlindung dari hujan dan terik matahari langsung, sehingga jumlah semen minimum yang dipakai adalah $325 \mathrm{Kg} / \mathrm{m}^{3}$, dengan nilai faktor air semen minimum 0,60 (PBI '71).

4. Nilai slum yang dikehendaki $80 \mathrm{~mm}$ sampai $120 \mathrm{~mm}$.

5. Ukuran butir agregat maksimum $1 \frac{1}{2}$ in.

6. Jenis agregat kasar Klungkung

7. Jenis agregat halus pasir Klungkung.

\subsubsection{Langkah-langkah Perhitungan Mix Design Beton}

1. Deviasi standard, dari tabel 4.5.1. PBI ' 71 deviasi standard antara 45 sampai 55 maka diambil nilai rata-rata $S=50 \mathrm{Kg} / \mathrm{cm}^{2}$.

2. Nilai tambah (margin) $=\mathrm{k} \times \mathrm{s} ; \mathrm{k}=1,64$ $=1,64 \times 50$

$=82 \mathrm{Kg} / \mathrm{cm}^{2}$.

3. Menentukan kuat tekan beton rata-rata yang ditargetkan ( $\left.f^{\prime} \mathrm{cr}\right)$

$F^{\prime} \mathrm{cr}=\mathrm{f}^{\prime} \mathrm{c}+1,64 \times \mathrm{s}$

$$
=225+1,64 \times 50=307 \mathrm{Kg} / \mathrm{cm}^{2} \text {. }
$$

4. Menentukan nilai faktor air semen.

Dari tabel 3.12 dapat diketahui perkiraan kuat tekan beton pada umur 3 hari, 7 hari, 28 hari, dan 91 hari, untuk faktor air semen 0,50

Tabel 3.12 Perkiraan Kuat Tekan Beton Dengan Faktor Air Semen 0,50.

\begin{tabular}{|c|c|c|c|c|c|}
\hline \multirow{2}{*}{$\begin{array}{c}\text { Type } \\
\text { semen }\end{array}$} & \multirow{2}{*}{$\begin{array}{c}\text { Type } \\
\text { agregat } \\
\text { kasar }\end{array}$} & \multicolumn{4}{|c|}{$\begin{array}{c}\text { Kuat tekan beton }\left(\mathrm{N} / \mathrm{mm}^{2}\right) \\
\text { Pada umur }\end{array}$} \\
\cline { 3 - 6 } & & 3 hari & 7 & 28 & 91 \\
hari & hari & hari \\
\hline \multirow{2}{*}{ Type I } & Koral & 18 & 27 & 40 & 48 \\
& Split & 23 & 33 & 47 & 55 \\
\hline \multirow{2}{*}{ Type III } & Koral & 25 & 34 & 46 & 53 \\
& Split & 30 & 40 & 53 & 60 \\
\hline \multirow{2}{*}{ Type V } & Koral & 18 & 27 & 40 & 48 \\
& Split & 23 & 33 & 47 & 55 \\
\hline
\end{tabular}

Sumber : SK SNI-T-15-1990-03 
Catatan: $1 \mathrm{Mpa}=10,145 \mathrm{Kg} / \mathrm{cm}^{2}$.

Untuk semen type I jenis agregat kasar adalah split pada tabel 3.12 diperoleh perkiraan kekuatan beton umur 28 hari $=47 \mathrm{Mpa}=476,815 \mathrm{Kg} / \mathrm{cm}^{2}$.

Jadi untuk F'cr $=307 \mathrm{Kg} / \mathrm{cm}^{2}=30,26 \mathrm{Mpa}$, nilai faktor air semennya dapat dicari dengan menggunakan grafik 3.1 yang diambil dari Properties of Concrete by AM Neville.

Caranya adalah sebagai berikut:

a. Pada sumbu vertikal cari harga $4,7 \mathrm{MPa}$ kemudian tarik garis horisontal yang memotong garis vertikal (yang melalui $\mathrm{W} / \mathrm{C}=0,50$ ) ketemu titik A.

b. Dari titik A kemudian dibuat lengkungan grafik.

c. Tarik garis horisontal melalui angka 30,26 Mpa pada sumbu vertikal yang akan memotong lengkung tersebut ketemu titik B.

d. Dari titik B tarik garis vertikal yang akan memotong sumbu horisontal, maka akan diperoleh $\mathrm{W} / \mathrm{C}=0,65$.

e. W/C maksimum diketahui 0,60 dari grafik 4.1 diperoleh $\mathrm{W} / \mathrm{C}=0,65$, kemudian harga $\mathrm{W} / \mathrm{C}$ yang dipakai adalah yang lebih kecil, yaitu 0,60.

Grafik 3.1. Hubungan antara kuat tekan dan faktor air semen.

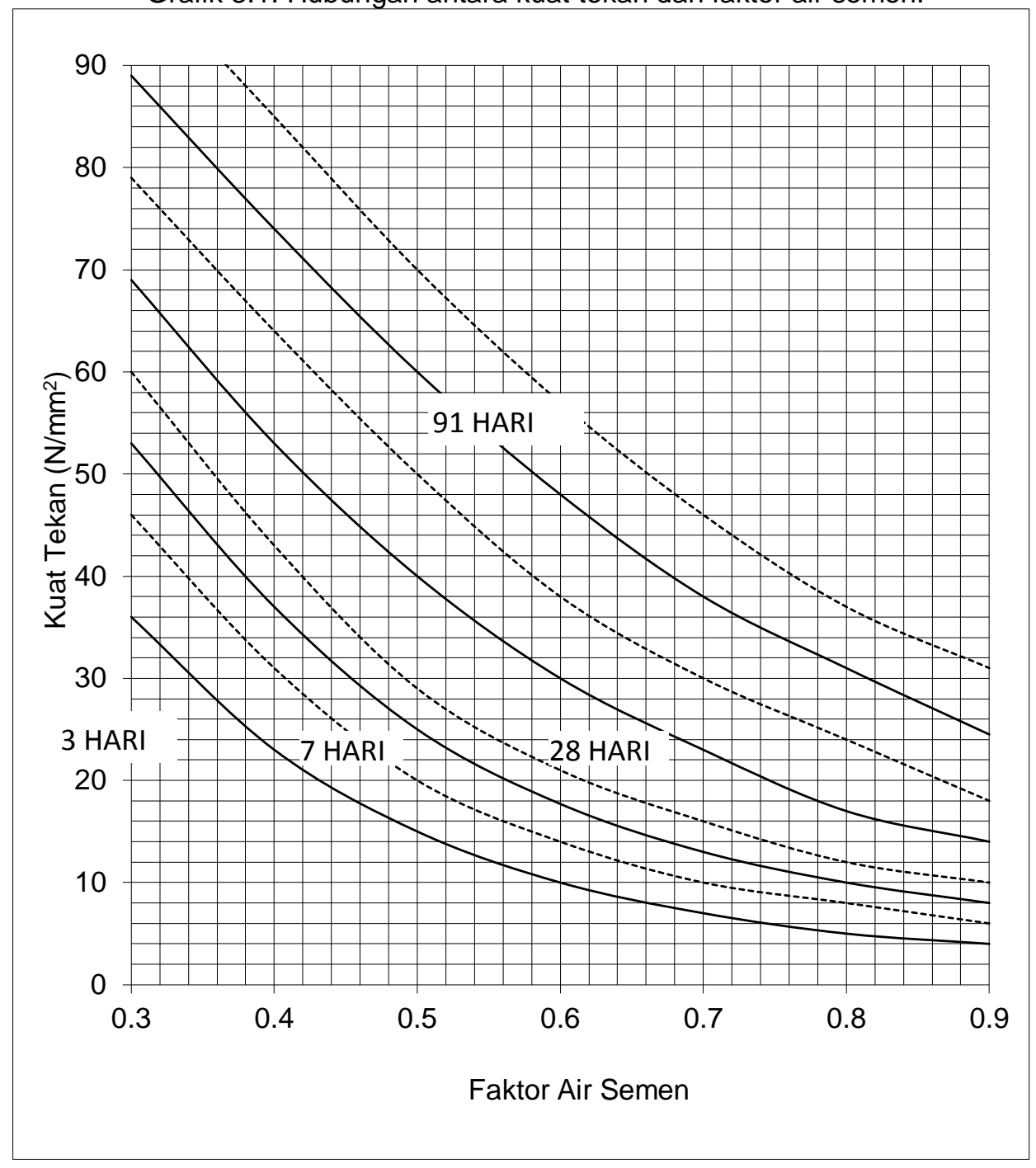

Sumber : SK SNI-T-15-1990-03

Semen tipe I, II dan IV

Semen Tipe III 
5. Menentukan kadar air bebas yang diperlukan untuk mencapai nilai slump $60 \mathrm{~mm}$ sampai $180 \mathrm{~mm}$ dengan menggunakan tabel 3.13

Tabel 3.13. Perkiraan kadar air bebas yang dibutuhkan untuk beberapa tingkat kemudahan pengerjaan beton

\begin{tabular}{|c|c|c|c|c|c|}
\hline \multicolumn{2}{|c|}{ Agregat kasar } & \multicolumn{4}{|c|}{$\begin{array}{c}\text { Jumlah air yang diperlukan (Kg/m³ } \\
\text { adukan untuk mencapai nilai slump } \\
(\mathrm{mm})\end{array}$} \\
\hline $\begin{array}{c}\text { Ukuran } \\
\text { maksimum } \\
(\mathrm{mm})\end{array}$ & $\begin{array}{c}\text { Type } \\
\text { Agregat }\end{array}$ & $0-10$ & $10-30$ & $\begin{array}{c}30- \\
60\end{array}$ & $60-180$ \\
\hline 10 & Split & 180 & 205 & 230 & 250 \\
& Koral & 150 & 180 & 205 & 225 \\
\hline 20 & Split & 170 & 190 & 210 & 225 \\
& Koral & 135 & 160 & 180 & 195 \\
\hline 40 & Split & 155 & 175 & 190 & 205 \\
& Koral & 115 & 140 & 160 & 175 \\
\hline
\end{tabular}

Sumber : SK SNI -T-15 -1990-03

Dalam penelitian ini nilai slump yang diinginkan adalah $60 \mathrm{~mm}-180 \mathrm{~mm}$, ukuran agregat maksimum $40 \mathrm{~mm}$, jenis agregat kasar adalah split, maka kadar air bebasnyan dicari dengan rumus : $2 / 3 \mathrm{Wh}+$ $1 / 3$ Wk.

Kadar air bebas $(\mathrm{W})=2 / 3 \mathrm{Wh}+1 / 3 \mathrm{Wk}$

$$
\begin{aligned}
& =2 / 3 \times 175 \\
& +1 / 3.205
\end{aligned}
$$$$
=185 \mathrm{~kg} / \mathrm{m}^{3}
$$

6. Menentukan jumlah semen

W/C diperoleh dari langkah no. d yaitu $\mathrm{W} / \mathrm{C}$

$$
\begin{aligned}
=0,60 & \\
W / C= & 0,60 \\
185 / C= & 0,60 \\
C= & 185 / 0,60=308,33 \mathrm{~kg} / \mathrm{m}^{3} \\
\mathrm{C}= & 308,33 \mathrm{~kg} / \mathrm{m}^{3} \text { lebih kecil dari } \\
& \text { jumlah semen minimum } \\
& \text { yang disyaratkan sebesar } \\
& 325 \mathrm{~kg} / \mathrm{m}^{3} .
\end{aligned}
$$

7. Menentukan letak zone pasir

Setelah digambar kurve gradasi pasir (dengan diperoleh dari hasil pemeriksaan gradasi pasir) pada ke 4 zone, ternyata pasir yang dipakai termasuk pada zone 2 .

8. Menentukan persentase pasir pada campuran agregat halus (pasir) + agregat kasar (Koral).

Dengan memakai grafik 2 yang diambil dari "Properties of Concrete" by AM. Neville, untuk ukuran agregat maksimum $40 \mathrm{~mm}$ dengan nilai slump $60 \mathrm{~mm}-180 \mathrm{~mm}$.

Grafik 3.2. Menentukan persentase jumlah pasir yang dianjurkan untuk daerah susunan butir No. 1, 2, 3, 4.
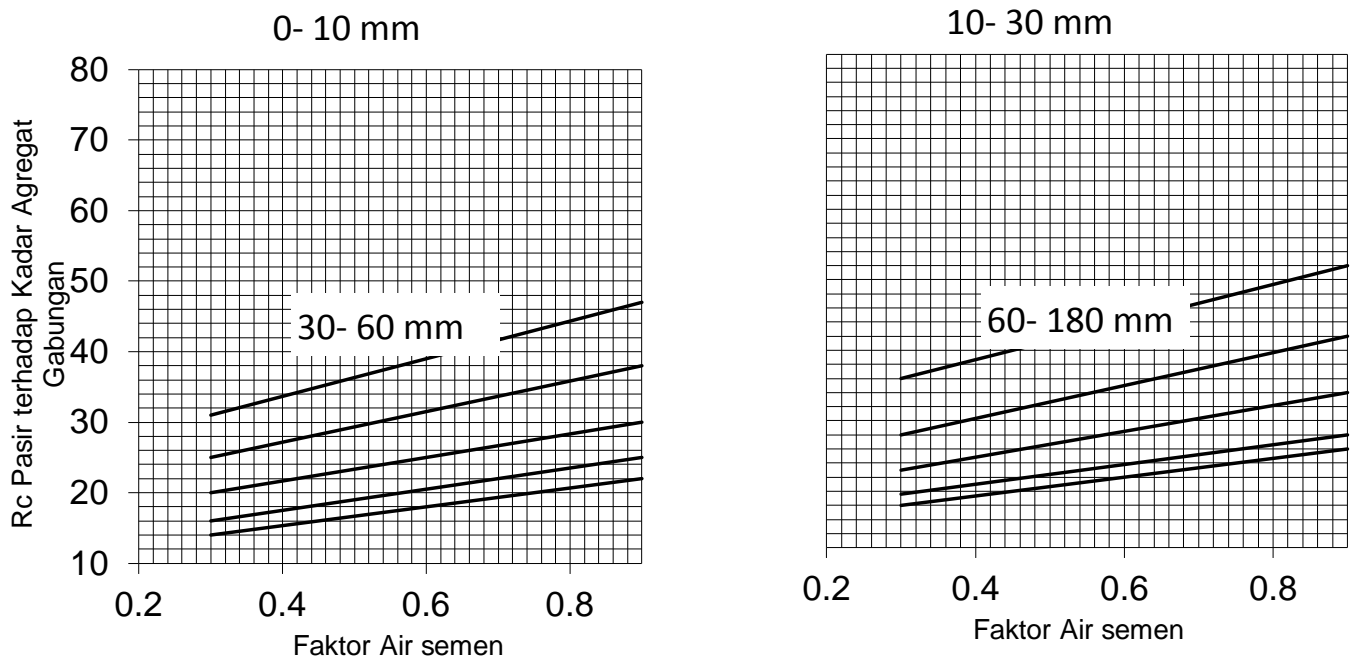


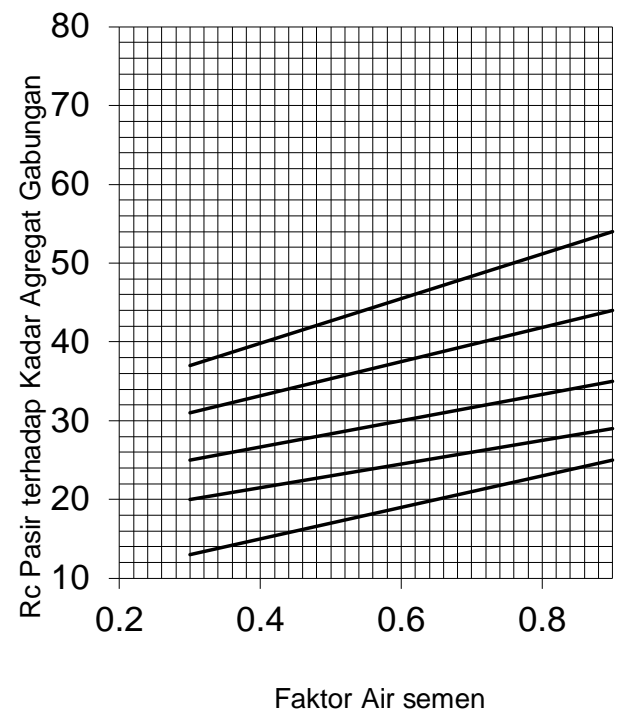

Cara penggunaan grafik 3.2 adalah sebagai berikut :

Cari nilai W/C (faktor air semen) $=0,60$, kemudian tarik garis vertikal memotong zone pasir 2, sehingga dari grafik di dapat persentase pasir antara $34 \%$ dan $44 \%$, kemudian dicari nilai rata-ratanya. Persentase pasir $=1 / 2(34 \%+44 \%)=$ $39 \%$

9. Menentukan berat jenis agregat gabungan

BJ. Agregat gabungan $=(\%$ agg. halus $x$ BJ. agg. halus $)+(\%$ agg. Kasar $x$ BJ. agg. kasar)

BJ. agregat gabungan $=(39 \% \times 2,444)$

$+(61 \% \times 2,483)$

BJ. agregat gabungan $=2,468 \mathrm{~kg} / \mathrm{liter}$

10. Menentukan berat jenis beton

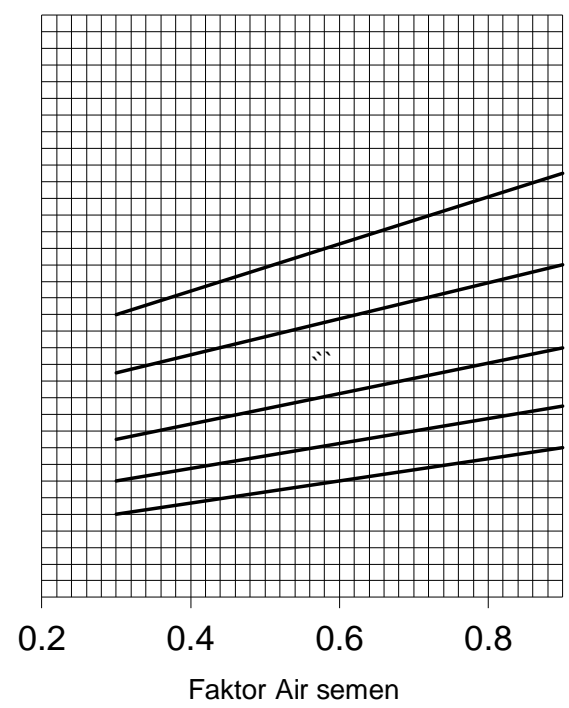

Untuk mendapatkan berat jenis beton dipakai grafik 4.3 yang dikutip dari properties of concrete by AM. Neville. Caranya adalah sebagai berikut:

a. Tentukan jumlah air bebas yang diperlukan untuk $1 \mathrm{~m}^{3}$ adukan beton, dari langkah No. e, didapat jumlah air bebas sebesar $(W)=185$ $\mathrm{kg} / \mathrm{m}^{3}$.

b. Selanjutnya pada grafik 4.3 dicari nilai 185, kemudian tarik garis vertikal yang memotong garis miring (garis yang melewati angka yang menunjukkan BJ agregat gabungan $=2,468 \mathrm{~kg} /$ liter). Dari titik perpotongan tersebut, tarik garis horisontal yang memotong ordinat yang menunjukkan berat jenis beton, dan dari grafik didapat BJ beton $=2275 \mathrm{~kg} / \mathrm{m}^{3}$. 
Grafik 3.3. Perkiraan berat jenis beton.

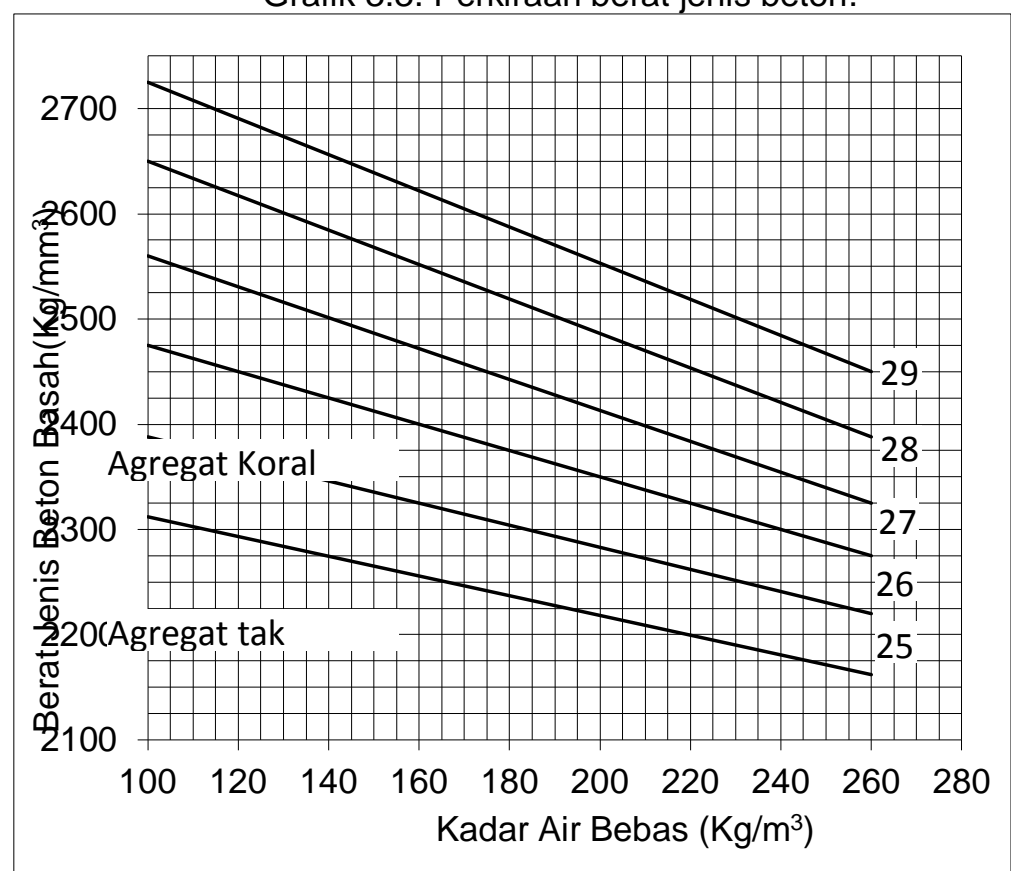

BERAT JENIS AGREGAT

GABUNGAN (PASIR, KERIKIL, KORAL ATAS

DASAR KERING

PERMUKAAN

Sumber : SK SNI-T-15-1990-03

11. Menentukan proporsi campuran beton

a. Kadar agregat gabungan

= BJ. beton - (jumlah kadar air bebas + semen)

$$
=2275-(185+325)=1765 \mathrm{~kg} / \mathrm{m}^{3}
$$

b. Kadar agregat halus

$=\%$ agregat halus $\mathrm{x}$ kadar agregat gabungan

$=39 \% \times 1765=0,39 \times 1765$

$=688,35 \mathrm{~kg} / \mathrm{m}^{3}$

c. Kadar agregat kasar

$=$ Kadar agregat gabungan - kadar agregat halus

$$
=1765-688,35=1076,65 \mathrm{~kg} / \mathrm{m}^{3}
$$

12. Hasil mix design beton dalam keadaan SSD.

Untuk $1 \mathrm{~m}^{3}$ beton diperlukan material dalam keadaan SSD adalah sebagai berikut:

Semen $=325 \mathrm{Kg}$

Pasir $=688,35 \mathrm{~kg}$

Koral $=1076,65 \mathrm{~kg}$

Air $\quad=185 \mathrm{~kg}$

13. Koreksi material campuran beton Karena dalam pembuatan benda uji kubus menggunakan agregat dalam keadaan sebenarnya, sedangkan mix design beton tersebut di atas menggunakan material dalam keadaan
SSD maka perlu dilakukan koreksi terhadap jumlah material campuran beton sebagai berikut:

$\begin{array}{lr}\text { Agregat halus } & =\mathrm{C}+(\mathrm{Ck}-\mathrm{Ca}) \mathrm{x} \\ \mathrm{C} / 100 & \\ \text { Agregat kasar } & =\mathrm{D}+(\mathrm{Dk}-\mathrm{Da}) \mathrm{x} \\ \mathrm{D} / 100 & \\ \text { Air } & \\ \mathrm{C} / 100- & \mathrm{b}-(\mathrm{Ck}-\mathrm{Ca}) \mathrm{x} \\ \mathrm{D} / 100 \mathrm{Da}) \mathrm{x}\end{array}$

$\mathrm{D} / 100$

Dimana:

$B=$ Jumlah air $=185 \mathrm{~kg} / \mathrm{m}^{3}$

$\mathrm{C}=$ jumlah agregat halus $=688,35$ $\mathrm{kg} / \mathrm{m}^{3}$

$\mathrm{D}=$ jumlah agregat kasar = $1076,65 \mathrm{~kg} / \mathrm{m}^{3}$

$\mathrm{Ca}=$ absorpsi air pada agregat halus $=1,978 \%$

$\mathrm{Da}=$ absorpsi air pada agregat kasar $=2,976 \%$

$\mathrm{Ck}=$ kandungan air dalam agregat halus $=5,11 \%$

$\mathrm{Dk}=$ Kandungan air dalam agregat kasar $=2,08 \%$

Koreksi hasil MIX design:
a. Agregat halus
$=688,35+(5,11 \%-1,978 \%) x$
$688,35 / 100$
$=688,565 \mathrm{~kg} / \mathrm{m}^{3}$
b. Agregat kasar$$
=1076,65+(2,08 \%-2,976 \%) x
$$ $1076,65 / 100$
$=1076,553 \mathrm{~kg} / \mathrm{m}^{3}$
c. Air 


$$
\begin{gathered}
=185-(5,11 \%-1,978 \%) x \\
688,35 / 100-(2,08 \%-2,976 \%) x \\
1076,65 / 100 \\
=184,881 \mathrm{~kg} / \mathrm{m}^{3}
\end{gathered}
$$

Jadi hasil mix design beton setelah dikoreksi adalah:

$$
\begin{array}{ll}
\text { Semen } & =325 \mathrm{~kg} / \mathrm{m}^{3} \\
\text { Pasir } & =688,565 \mathrm{~kg} / \mathrm{m}^{3} \\
\text { Koral } & =1076,553 \mathrm{~kg} / \mathrm{m}^{3} \\
\text { Air } & =184,881 \mathrm{~kg} / \mathrm{m}^{3}
\end{array}
$$

\subsection{Pembuatan Campuran Beton}

Dalam penelitian ini campuran beton dibuat untuk 4 (empat) perlakuan dimana untuk $1 \mathrm{~m}^{3}$ beton dan 10 benda uji diperlukan material dalam keadaan SSD dapat dilihat pada table sebagai berikut:

Tabel 2.14 Kebutuhan Bahan Dalam Keadaan SSD Untuk $1 \mathrm{~m}^{3}$

\begin{tabular}{|l|l|l|l|l|l|}
\hline $\begin{array}{l}\text { Nama } \\
\text { Bahan }\end{array}$ & $\begin{array}{c}\mathrm{Kg} / \\
\mathrm{m}^{3}\end{array}$ & \multicolumn{5}{|c|}{ Kebutuhan Bahan Untuk $1 \mathrm{~m}^{3}$} \\
\cline { 3 - 6 } & & $\begin{array}{c}0 \mathrm{cc} \\
(\mathrm{Kg})\end{array}$ & $\begin{array}{c}80 \mathrm{cc} \\
(\mathrm{Kg})\end{array}$ & $\begin{array}{c}120 \mathrm{cc} \\
(\mathrm{Kg})\end{array}$ & $\begin{array}{c}200 \mathrm{cc} \\
(\mathrm{Kg})\end{array}$ \\
\hline $\begin{array}{l}\text { Seme } \\
\mathrm{n}\end{array}$ & 325 & 325 & 325 & 325 & 325 \\
\hline Pasir & 688, & 688,5 & 688,56 & 688,56 & 688,56 \\
& 565 & 65 & 5 & 5 & 5 \\
\hline Koral & 1076 & $\begin{array}{l}1076, \\
553\end{array}$ & $\begin{array}{l}1076,5 \\
53\end{array}$ & $\begin{array}{l}1076,5 \\
53\end{array}$ & $\begin{array}{l}1076,5 \\
53\end{array}$ \\
\hline $\begin{array}{l}\text { Addito } \\
\mathrm{n} \text { H.E }\end{array}$ & 0 & 0 & 520 & 780 & 1300 \\
\hline Air & 184, & 184,8 & $\begin{array}{l}184,88 \\
1\end{array}$ & $\begin{array}{l}184,88 \\
1\end{array}$ & $\begin{array}{l}184,88 \\
1\end{array}$ \\
\hline
\end{tabular}

Sumber : Hasil Mix Design

Tabel 3.15 Kebutuhan Bahan Untuk 10 Benda uji (Kg)

\begin{tabular}{|l|l|l|l|l|l|}
\hline $\begin{array}{l}\text { Nama } \\
\text { Bahan }\end{array}$ & $\mathrm{Kg} / \mathrm{m}^{3}$ & \multicolumn{4}{|c|}{ Kebutuhan Bahan Untuk 10 Benda } \\
Uji ( Kg ) \\
\cline { 3 - 6 }
\end{tabular}

Sumber : Hasil Mix Design

\subsection{Hasil Pengujian Beton}

\subsubsection{Hasil Pengujian Nilai Slump}

Sebelum memulai pembuatan benda uji, terlebih dahulu dilakukan pengujian slump pada adukan beton. Ini dilakukan untuk menjamin agar nilai air semen tetap sesuai rencana. Nilai slump diambil adalah $80 \mathrm{~mm}$ sampai $120 \mathrm{~mm}$.

Control untuk Slump Test

Upper Control Limit $=120 \mathrm{~mm}$

Lower Control Limit $=80 \mathrm{~mm}$

Target Value

$=(120+80): 2=$

$100 \mathrm{~mm}$

Upper Warning Limit $=120-(120 \times 5 \%)$

\begin{tabular}{|c|c|c|c|c|c|}
\hline $\begin{array}{c}\text { Benda } \\
\text { Uji }\end{array}$ & $\begin{array}{l}\text { Ula- } \\
\text { ngan }\end{array}$ & $\begin{array}{c}\mathrm{I} \\
0 \mathrm{cc} \\
(\mathrm{Cm})\end{array}$ & $\begin{array}{c}11 \\
80 \mathrm{cc} \\
(\mathrm{Cm})\end{array}$ & $\begin{array}{c}\text { III } \\
120 \mathrm{cc} \\
(\mathrm{Cm})\end{array}$ & $\begin{array}{c}\mathrm{IV} \\
200 \mathrm{cc} \\
(\mathrm{Cm})\end{array}$ \\
\hline \multirow{3}{*}{$\begin{array}{l}\text { Kubus } \\
15 \times 15 \times 1 \\
5\end{array}$} & 1 & 10,80 & 10,70 & 10,60 & 10,30 \\
\hline & 2 & 10,90 & 10,70 & 10,60 & 10,40 \\
\hline & $\begin{array}{l}\text { Rata- } \\
\text { rata }\end{array}$ & 10,85 & 10,70 & 10,60 & 10,35 \\
\hline
\end{tabular}

$$
=114 \mathrm{~mm}
$$

Lower warning Limit $=80-(80 \times 5 \%)$

$$
=79,95 \mathrm{~mm}
$$

Hasil pengujian nilai slump kubus beton tiap percobaan ditabelkan sebagai berikut :

Tabel 3.16. Hasil Pengujian Nilai Slump

Dari Tabel 3.16 diketahui bahwa penambahan Additon H.E berpengaruh pada nilai Slump. Hal ini disebabkan karena Zat kimia tertentu yang terdapat dalam campuran Additon H.E mempengaruhi campuran beton sehingga beton cepat mengering. 


\subsubsection{Hasil Pengujian Kuat Tekan Beton}

Untuk mengetahui kuat tekan beton dari masing-masing benda uji untuk tiap percobaan, maka dilakukan test kuat tekan beton dengan menggunakan mesin uji kuat tekan beton dengan kapasitas 150 ton. Pengujian ini dilakukan pada empat percobaan / perlakuan dimana tiap percobaan / perlakuan terdiri dari 10 benda uji (Subakti, A., 1986).

1. Perlakuan I dalam hal ini sebagai kontrol, yaitu pengujian dilakukan pada campuran beton yang tidak dilakukan penambahan Additon H.E, dengan dosis 0 cc
2. Perlakuan II adalah campuran beton yang telah dilakukan penambahan Additon H.E, dengan dosis $80 \mathrm{cc}$

3. Perlakuan III adalah campuran beton yang telah dilakukan penambahan Additon H.E, dengan dosis $120 \mathrm{cc}$

4. Perlakuan IV adalah campuran beton yang telah dilakukan penambahan Additon H.E, dengan dosis $200 \mathrm{cc}$

Umur benda uji pada saat di test 7,14,21 dan 28 hari (Wangsadinata, W., 1971). hasil test kubus beton tiap percobaan / perlakuan ditabelkan sebagai berikut :

Tabel 3.17 Hasil Test Kubus Beton $15 \times 15 \times 15$ umur 7 hari $(0 \mathrm{cc})$

\begin{tabular}{|c|c|c|c|c|c|c|}
\hline $\begin{array}{l}N \\
0\end{array}$ & $\begin{array}{c}\text { Umur } \\
\text { Benda } \\
\text { Uji }\end{array}$ & $\begin{array}{c}\text { Berat } \\
\text { Kering } \\
\text { Beton } \\
(\mathrm{gr})\end{array}$ & $\begin{array}{c}\text { Beban } \\
\text { Max } \\
(\mathrm{kg})\end{array}$ & $\begin{array}{c}\text { Tegangan } \\
\text { Beton }\left(\sigma^{1} b\right) \\
\left(\mathrm{kg} / \mathrm{cm}^{2}\right)\end{array}$ & $\begin{array}{l}\sigma^{1} b- \\
\sigma^{1} b m\end{array}$ & $\begin{array}{l}\left(\sigma^{1} b-\right. \\
\left.\sigma^{1} b m\right)^{2}\end{array}$ \\
\hline 1 & 7 hari & 7120 & 50000 & 144,44 & 0,57 & 0,32 \\
\hline 2 & 7 hari & 7230 & 48000 & 138,67 & $-5,20$ & 27,04 \\
\hline 3 & 7 hari & 7250 & 49000 & 141,56 & $-2,31$ & 5,34 \\
\hline 4 & 7 hari & 7280 & 50000 & 144,44 & 0,57 & 0,32 \\
\hline 5 & 7 hari & 7510 & 50000 & 144,44 & 0,57 & 0,32 \\
\hline 6 & 7 hari & 7600 & 49000 & 141,56 & $-2,31$ & 5,34 \\
\hline 7 & 7 hari & 7380 & 51000 & 147,33 & 3,46 & 11,97 \\
\hline 8 & 7 hari & 7085 & 51000 & 147,33 & 3,46 & 11,97 \\
\hline 9 & 7 hari & 7133 & 50000 & 144,44 & 0,57 & 0,32 \\
\hline $\begin{array}{l}1 \\
0\end{array}$ & 7 hari & 7134 & 50000 & 144,44 & 0,57 & 0,32 \\
\hline & & & & $1.438,65$ & & 63,26 \\
\hline
\end{tabular}

fu : 7 hari $=0,65$

$\mathrm{fb}:$ kubus $15 \times 15 \times 15 \mathrm{~cm}=1,00$

$\sigma^{1} b=\frac{P}{A} x f u x f b$

$\sigma^{1} b m=\frac{\sum_{1}^{n} \sigma^{1} b}{n}=\frac{1.438,65}{10}=143,87$
$\mathrm{S}=$

$\sqrt{\frac{\sum_{1}^{n}\left(\sigma^{1} b-\sigma^{1} b m\right)^{2}}{N-1}}=\sqrt{\frac{63,26}{9}}=2,65$

$\sigma^{1} b k=\sigma^{1} b m$ - k.s $\quad=143,87-1,83$.

2,65 
Tabel 3.18 Hasil Test Kubus Beton $15 \times 15$ x 15 umur 7 hari (80 cc)

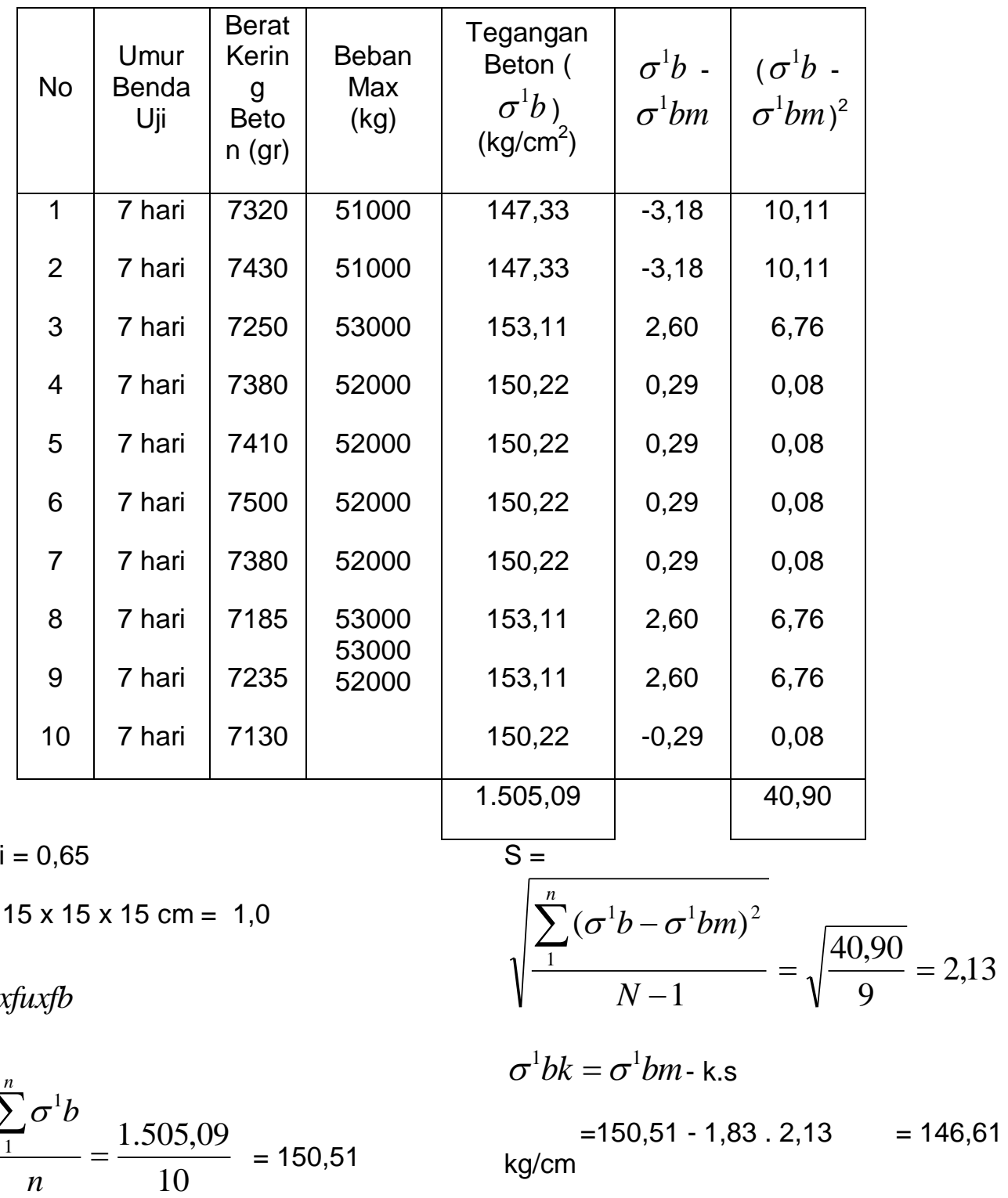

Tabel 3.19 Hasil Test Kubus Beton $15 \times 15 \times 15$ umur 7 hari (120 cc)

\begin{tabular}{|c|c|c|c|c|c|c|}
\hline $\begin{array}{c}\mathrm{N} \\
\mathrm{O}\end{array}$ & $\begin{array}{c}\text { Umur } \\
\text { Benda } \\
\text { Uji }\end{array}$ & $\begin{array}{c}\text { Berat } \\
\text { Kering } \\
\text { Beton } \\
(\mathrm{gr})\end{array}$ & $\begin{array}{c}\text { Beban } \\
\text { Max } \\
(\mathrm{kg})\end{array}$ & $\begin{array}{c}\text { Tegangan } \\
\text { Beton }\left(\sigma^{1} b\right) \\
\left(\mathrm{kg} / \mathrm{cm}^{2}\right)\end{array}$ & $\begin{array}{c}\sigma^{1} b- \\
\sigma^{1} b m\end{array}$ & $\begin{array}{c}\left(\sigma^{1} b-\right. \\
\left.\sigma^{1} b m\right)^{2}\end{array}$ \\
\hline 1 & 7 hari & 7125 & 56000 & 161,78 & $-1,16$ & 1,35 \\
2 & 7 hari & 7330 & 57000 & 164,67 & 1,73 & 2,99 \\
3 & 7 hari & 7250 & 57000 & 164,67 & 1,73 & 2,99 \\
4 & 7 hari & 7180 & 56000 & 161,78 & $-1,16$ & 1,35 \\
\hline
\end{tabular}




\begin{tabular}{|c|c|c|c|c|c|c|}
\hline 5 & 7 hari & 7210 & 56000 & 161,78 & $-1,16$ & 1,35 \\
6 & 7 hari & 7500 & 57000 & 164,67 & 1,73 & 2,99 \\
7 & 7 hari & 7180 & 57000 & 164,67 & 1,73 & 2,99 \\
8 & 7 hari & 7285 & 55000 & 158,89 & 4,05 & 16,40 \\
9 & 7 hari & 7430 & 57000 & 164,67 & 1,73 & 2,99 \\
10 & 7 hari & 7210 & 56000 & 161,78 & $-1,16$ & 1,35 \\
\hline
\end{tabular}

$$
\begin{array}{ll}
\text { fu : } 7 \text { hari }=0,65 & \mathrm{~S}= \\
\mathrm{fb}: \text { kubus } 15 \times 15 \times 15 \mathrm{~cm}=1,0 & \sqrt{\frac{\sum_{1}^{n}\left(\sigma^{1} b-\sigma^{1} b m\right)^{2}}{N-1}}=\sqrt{\frac{36,75}{9}}=2,02 \\
\sigma^{1} b=\frac{P}{A} \times f u x f b & \sigma^{1} b k=\sigma^{1} b m-\mathrm{k} \cdot \mathrm{s} \\
\sigma^{1} b m=\frac{\sum_{1}^{n} \sigma^{1} b}{n}=\frac{1.629,36}{10}=162,94 & \mathrm{~kg} / \mathrm{cm}=162,94-1,83 \cdot 2,02=159,63
\end{array}
$$

Tabel 3.20 Hasil Test Kubus Beton $15 \times 15 \times 15$ umur 7 hari $(200 \mathrm{cc}$ )

\begin{tabular}{|c|c|c|c|c|c|c|}
\hline No & $\begin{array}{c}\text { Umur } \\
\text { Benda } \\
\text { Uji }\end{array}$ & $\begin{array}{c}\text { Berat } \\
\text { Kering } \\
\text { Beton } \\
(\mathrm{gr})\end{array}$ & $\begin{array}{c}\text { Beban } \\
\text { Max } \\
(\mathrm{kg})\end{array}$ & $\begin{array}{c}\text { Tegangan } \\
\text { Beton }( \\
\left.\sigma^{1} b\right) \\
\left(\mathrm{kg} / \mathrm{cm}^{2}\right)\end{array}$ & $\begin{array}{c}\sigma^{1} b- \\
\sigma^{1} b m\end{array}$ & $\left(\sigma^{1} b-\sigma^{1} b m\right)^{2}$ \\
\hline 1 & 7 hari & 7320 & 62000 & 179,11 & $-4,34$ & 18,84 \\
2 & 7 hari & 7230 & 64000 & 184,89 & 1,44 & 2,07 \\
3 & 7 hari & 7250 & 63000 & 182,00 & $-1,45$ & 2,10 \\
4 & 7 hari & 7280 & 63000 & 182,00 & $-1,45$ & 2,10 \\
5 & 7 hari & 7110 & 64000 & 184,89 & 1,44 & 2,07 \\
6 & 7 hari & 7150 & 64000 & 184,89 & 1,44 & 2,07 \\
7 & 7 hari & 7480 & 63000 & 182,00 & $-1,45$ & 2,10 \\
8 & 7 hari & 7285 & 65000 & 187,78 & 4,33 & 18,75 \\
9 & 7 hari & 7535 & 64000 & 184,89 & 1,44 & 2,07 \\
10 & 7 hari & 7340 & 63000 & 182,00 & $-1,45$ & 2,10 \\
& & & & &
\end{tabular}


fu : 7 hari $=0,65$

$\mathrm{fb}$ : kubus $15 \times 15 \times 15 \mathrm{~cm}=1,0$

$\sigma^{1} b=\frac{P}{A} x f u x f b$

$\sigma^{1} b m=\frac{\sum_{1}^{n} \sigma^{1} b}{n}=\frac{1.834,45}{10}=183,45$
$\mathrm{S}=$

$\sqrt{\frac{\sum_{1}^{n}\left(\sigma^{1} b-\sigma^{1} b m\right)^{2}}{N-1}}=\sqrt{\frac{54,27}{9}}=2,46$

$\sigma^{1} b k=\sigma^{1} b m-\mathrm{k} . \mathrm{s}$

$\mathrm{kg} / \mathrm{cm}$ $=183,45-1,83 \cdot 2,46=178,95$

Tabel 3.21 Hasil Test Kubus Beton $15 \times 15 \times 15$ umur 14 hari $(0 \mathrm{cc})$

\begin{tabular}{|c|c|c|c|c|c|c|}
\hline $\begin{array}{l}\mathrm{N} \\
\mathrm{O}\end{array}$ & $\begin{array}{c}\text { Umur } \\
\text { Benda Uji }\end{array}$ & $\begin{array}{c}\text { Berat } \\
\text { Kering } \\
\text { Beton } \\
(\mathrm{gr})\end{array}$ & $\begin{array}{c}\text { Beban } \\
\text { Max } \\
(\mathrm{kg})\end{array}$ & $\begin{array}{c}\text { Tegangan } \\
\text { Beton ( } \\
\left.\sigma^{1} b\right) \\
\left(\mathrm{kg} / \mathrm{cm}^{2}\right)\end{array}$ & $\begin{array}{l}\sigma^{1} b- \\
\sigma^{1} b m\end{array}$ & $\begin{array}{l}\left(\sigma^{1} b\right. \\
\left.\sigma^{1} b m\right)^{2}\end{array}$ \\
\hline 1 & 14 hari & 7210 & 58000 & 226,84 & 0 & 0 \\
\hline 2 & 14 hari & 6995 & 59000 & 230,76 & 3,92 & 15,37 \\
\hline 3 & 14 hari & 7280 & 58000 & 226,84 & 0 & 0 \\
\hline 4 & 14 hari & 7245 & 57000 & 222,93 & $-3,91$ & 15,29 \\
\hline 5 & 14 hari & 7195 & 58000 & 226,84 & 0 & 0 \\
\hline 6 & 14 hari & 7090 & 58000 & 226,84 & 0 & 0 \\
\hline 7 & 14 hari & 7125 & 59000 & 230,76 & 3,92 & 15,37 \\
\hline 8 & 14 hari & 7375 & 57000 & 222,93 & $-3,91$ & 15,29 \\
\hline 9 & 14 hari & 7135 & 58000 & 226,84 & 0 & 0 \\
\hline 10 & 14 hari & 7140 & 58000 & 226,84 & 0 & 0 \\
\hline & & & & $2.268,42$ & & 61,32 \\
\hline
\end{tabular}

fu : 14 hari $=0,88$

$\mathrm{S}=$

$\mathrm{fb}$ : kubus $15 \times 15 \times 15 \mathrm{~cm}=1,0$

$\sqrt{\frac{\sum_{1}^{n}\left(\sigma^{1} b-\sigma^{1} b m\right)^{2}}{N-1}}=\sqrt{\frac{61,32}{9}}=2,62$

$\sigma^{1} b=\frac{P}{A} x f u x f b$

$\sigma^{1} b k=\sigma^{1} b m-\mathrm{k} . \mathrm{s}$

$\sigma^{1} b m=\frac{\sum_{1}^{n} \sigma^{1} b}{n}=\frac{2.268,42}{10}=226,84$

$\mathrm{kg} / \mathrm{cm}$ 
Tabel 3.22 Hasil Test Kubus Beton $15 \times 15$ x 15 umur 14 hari (80 cc)

\begin{tabular}{|c|c|c|c|c|c|c|}
\hline $\mathrm{N}$ & $\begin{array}{c}\text { Umur } \\
\text { Benda } \\
\text { Uji }\end{array}$ & $\begin{array}{c}\text { Berat } \\
\text { Kering } \\
\text { Beton } \\
(\mathrm{gr})\end{array}$ & $\begin{array}{c}\text { Beban } \\
\text { Max } \\
(\mathrm{kg})\end{array}$ & $\begin{array}{c}\text { Tegangan } \\
\text { Beton }( \\
\left.\sigma^{1} b\right) \\
\left(\mathrm{kg} / \mathrm{cm}^{2}\right)\end{array}$ & $\begin{array}{c}\sigma^{1} b- \\
\sigma^{1} b m\end{array}$ & $\left(\sigma^{1} b-\sigma^{1} b m\right)^{2}$ \\
\hline 1 & 14 hari & 7235 & 59000 & 230,76 & 1,57 & 2,46 \\
3 & 14 hari & 7210 & 58000 & 226,84 & $-2,35$ & 5,52 \\
4 & 14 hari & 6870 & 58000 & 226,84 & $-2,35$ & 5,52 \\
5 & 14 hari & 7127 & 58000 & 226,84 & $-2,35$ & 5,52 \\
6 & 14 hari & 7237 & 58000 & 226,84 & $-2,35$ & 2,46 \\
7 & 14 hari & 7215 & 58000 & 226,84 & $-2,35$ & 5,52 \\
8 & 14 hari & 7075 & 59000 & 230,76 & 1,57 & 5,52 \\
9 & 14 hari & 7150 & 60000 & 234,67 & 5,48 & 2,46 \\
1 & 14 hari & 7245 & 59000 & 230,76 & 1,57 & 30,03 \\
\hline
\end{tabular}

fu : 14 hari $=0,88$

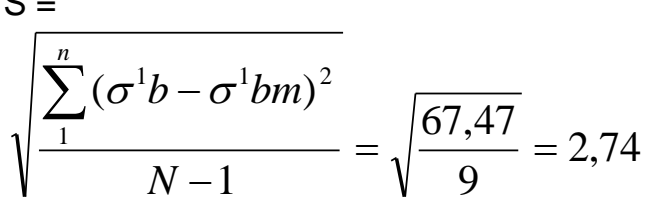

$\sigma^{1} b=\frac{P}{A} x f u x f b$

$\sigma^{1} b k=\sigma^{1} b m-\mathrm{k} . \mathrm{s}$

$\sigma^{1} b m=\frac{\sum_{1}^{n} \sigma^{1} b}{n}=\frac{2.291,91}{10}=229,19$

$=229,19-1,83 \cdot 2,74=224,18$

$\mathrm{kg} / \mathrm{cm}$

Tabel 3.23 Hasil Test Kubus Beton $15 \times 15$ x 15 umur 14 hari (120 cc)

\begin{tabular}{|c|c|c|c|c|c|c|}
\hline No & $\begin{array}{c}\text { Umur } \\
\text { Benda } \\
\text { Uji }\end{array}$ & $\begin{array}{c}\text { Berat } \\
\text { Kering } \\
\text { Beton } \\
\text { (gr) }\end{array}$ & $\begin{array}{c}\text { Beban } \\
\text { Max } \\
(\mathrm{kg})\end{array}$ & $\begin{array}{l}\text { Tegangan } \\
\text { Beton ( } \\
\left.\sigma^{1} b\right) \\
\left(\mathrm{kg} / \mathrm{cm}^{2}\right)\end{array}$ & $\begin{array}{l}\sigma^{1} b- \\
\sigma^{1} b m\end{array}$ & $\left(\begin{array}{c}\sigma^{1} b-\sigma^{1} b m \\
)^{2}\end{array}\right.$ \\
\hline 1 & 14 hari & 7155 & 60000 & 234,67 & $-5,87$ & 34,46 \\
\hline 2 & 14 hari & 7210 & 61000 & 238,58 & $-1,96$ & 3,84 \\
\hline 3 & 14 hari & 7260 & 61000 & 238,58 & $-1,96$ & 3,84 \\
\hline 4 & 14 hari & 7170 & 62000 & 242,49 & 1,95 & 3,80 \\
\hline 5 & 14 hari & 7560 & 62000 & 242,49 & 1,95 & 3,80 \\
\hline
\end{tabular}




\begin{tabular}{|c|c|c|c|c|c|c|}
\hline 6 & 14 hari & 7095 & 62000 & 242,49 & 1,95 & 3,80 \\
7 & 14 hari & 7215 & 61000 & 238,58 & $-1,96$ & 3,84 \\
8 & 14 hari & 7050 & 63000 & 246,40 & 5,86 & 34,34 \\
9 & 14 hari & 7120 & 61000 & 238,58 & $-1,96$ & 3,84 \\
10 & 14 hari & 7210 & 62000 & 242,49 & 1,95 & 3,80 \\
& & & $2.405,35$ & & 99,36 \\
& & &
\end{tabular}

fu : 14 hari $=0,88$

fb : kubus $15 \times 15 \times 15 \mathrm{~cm}=1,0$

$\sigma^{1} b=\frac{P}{A} x f u x f b$

$\sigma^{1} b m=\frac{\sum_{1}^{n} \sigma^{1} b}{n}=\frac{2.405,35}{10}=240,54$
$\mathrm{S}=$

$\sqrt{\frac{\sum_{1}^{n}\left(\sigma^{1} b-\sigma^{1} b m\right)^{2}}{N-1}}=\sqrt{\frac{240,54}{9}}=3,32$

$\sigma^{1} b k=\sigma^{1} b m-\mathrm{k} . \mathrm{s}$

$\mathrm{kg} / \mathrm{cm}$
$=240,54-1,83.3,32=234,46$

Tabel 3.24 Hasil Test Kubus Beton $15 \times 15 \times 15$ umur 14 hari $(200 \mathrm{cc})$

\begin{tabular}{|c|c|c|c|c|c|c|}
\hline No & $\begin{array}{c}\text { Umur } \\
\text { Benda } \\
\text { Uji }\end{array}$ & $\begin{array}{c}\text { Berat } \\
\text { Kering } \\
\text { Beton } \\
(\mathrm{gr})\end{array}$ & $\begin{array}{c}\text { Beban } \\
\text { Max } \\
(\mathrm{kg})\end{array}$ & $\begin{array}{c}\text { Tegangan } \\
\text { Beton }( \\
\left.\sigma^{1} b\right) \\
\left(\mathrm{kg} / \mathrm{cm}^{2}\right)\end{array}$ & $\begin{array}{c}\sigma^{1} b- \\
\sigma^{1} b m\end{array}$ & $\left(\sigma^{1} b-\sigma^{1} b m\right)^{2}$ \\
\hline 1 & 14 hari & 7155 & 66000 & 250,31 & $-2,74$ & 7,51 \\
3 & 14 hari & 7210 & 64000 & 250,31 & $-2,74$ & 7,51 \\
4 & 14 hari & 7260 & 65000 & 254,22 & 1,17 & 1,37 \\
5 & 14 hari & 7170 & 64000 & 250,31 & $-2,74$ & 7,51 \\
6 & 14 hari & 7160 & 65000 & 254,22 & 1,17 & 1,37 \\
7 & 14 hari & 7095 & 65000 & 254,22 & 1,17 & 1,37 \\
8 & 14 hari & 7215 & 65000 & 254,22 & 1,17 & 1,37 \\
9 & 14 hari & 7125 & 65000 & 254,22 & 1,17 & 1,37 \\
10 & 14 hari & 7130 & 64000 & 250,31 & $-2,74$ & 7,51 \\
\cline { 5 - 7 } & & & $2.530,47$ & & 62,70 \\
\cline { 5 - 6 } & & & &
\end{tabular}




$$
\begin{aligned}
& \mathrm{fu}: 14 \text { hari }=0,88 \\
& \text { fb : kubus } 15 \times 15 \times 15 \mathrm{~cm}=1,0 \\
& \sigma^{1} b=\frac{P}{A} x f u x f b \\
& \mathrm{~S}= \\
& \sigma^{1} b m=\frac{\sum_{1}^{n} \sigma^{1} b}{n}=\frac{2.530,47}{10}=253,05 \\
& \sqrt{\frac{\sum_{1}^{n}\left(\sigma^{1} b-\sigma^{1} b m\right)^{2}}{N-1}}=\sqrt{\frac{62,70}{9}}=2,64 \\
& \sigma^{1} b k=\sigma^{1} b m-\text { k.s } \\
& \mathrm{kg} / \mathrm{cm}=253,05-1,83.2,64=248,22
\end{aligned}
$$

Tabel 3.25 Hasil Test Kubus Beton $15 \times 15 \times 15$ umur 21 hari $(0 \mathrm{cc})$

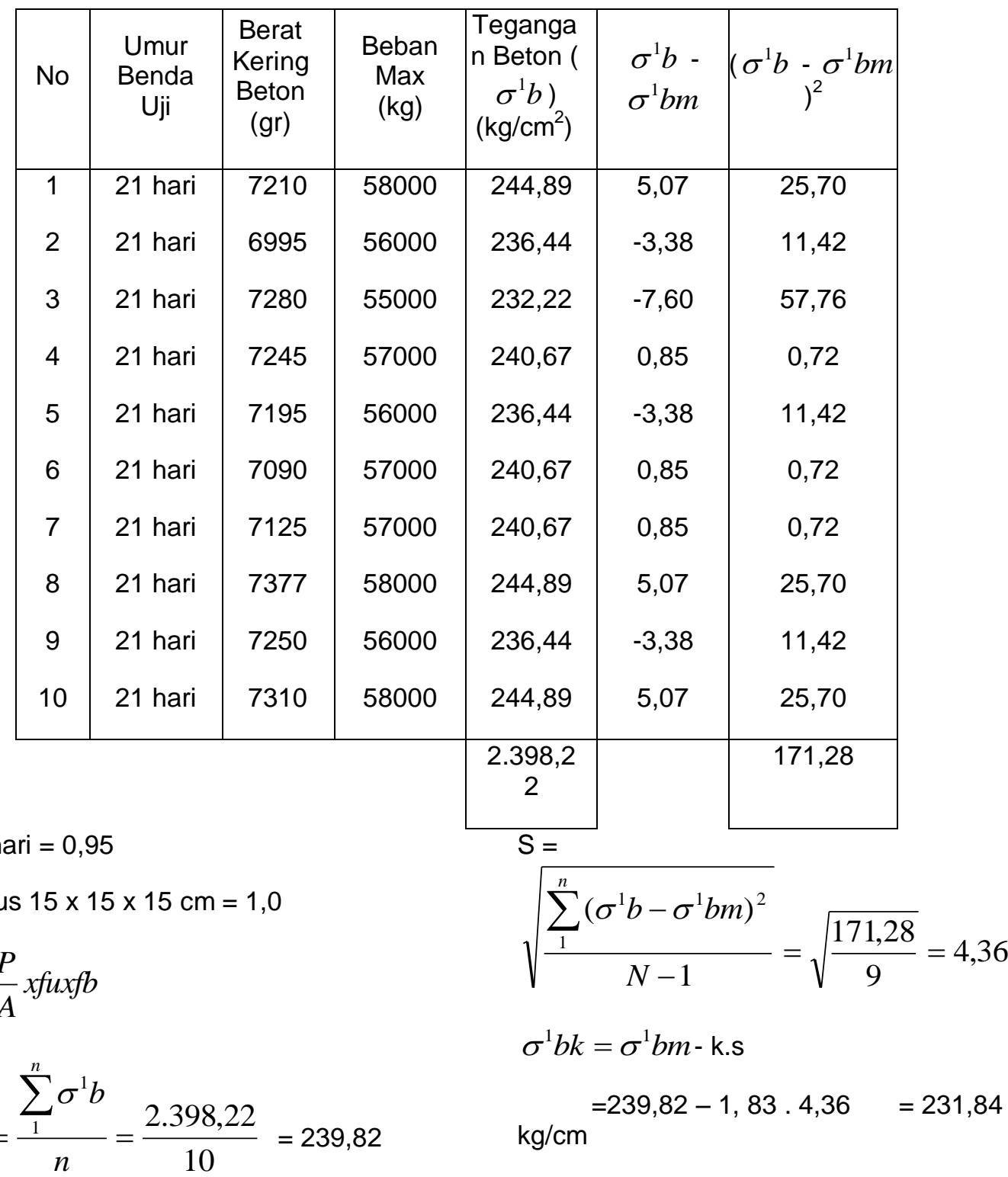

$\mathrm{fu}: 21$ hari $=0,95$

$\mathrm{fb}$ : kubus $15 \times 15 \times 15 \mathrm{~cm}=1,0$

$\sigma^{1} b=\frac{P}{A} x f u x f b$

$\sigma^{1} b m=\frac{\sum_{1}^{n} \sigma^{1} b}{n}=\frac{2.398,22}{10}=239,82 \quad \mathrm{~kg} / \mathrm{cm}=239,82-1,83 \cdot 4,36=231,84$ 
Tabel 3.26 Hasil Test Kubus Beton $15 \times 15$ x 15 umur 21 hari (80 cc)

\begin{tabular}{|c|c|c|c|c|c|c|}
\hline No & $\begin{array}{c}\text { Umur } \\
\text { Benda } \\
\text { Uji }\end{array}$ & $\begin{array}{c}\text { Berat } \\
\text { Kering } \\
\text { Beton } \\
\text { (gr) }\end{array}$ & $\begin{array}{c}\text { Beban } \\
\text { Max } \\
(\mathrm{kg})\end{array}$ & $\begin{array}{c}\text { Tegangan } \\
\text { Beton ( } \\
\left.\sigma^{1} b\right) \\
\left(\mathrm{kg} / \mathrm{cm}^{2}\right)\end{array}$ & $\begin{array}{l}\sigma^{1} b- \\
\sigma^{1} b m\end{array}$ & $\begin{array}{l}\left(\sigma^{1} b-\right. \\
\left.\sigma^{1} b m\right)^{2}\end{array}$ \\
\hline 1 & 21 hari & 7235 & 63000 & 266,00 & $-3,80$ & 14,44 \\
\hline 2 & 21 hari & 7210 & 63000 & 266,00 & $-3,80$ & 14,44 \\
\hline 3 & 21 hari & 6975 & 64000 & 270,22 & 0,42 & 0,18 \\
\hline 4 & 21 hari & 7127 & 65000 & 274,44 & 4,64 & 21,53 \\
\hline 5 & 21 hari & 7233 & 64000 & 270,22 & 0,42 & 0,18 \\
\hline 6 & 21 hari & 7237 & 64000 & 270,22 & 0,42 & 0,18 \\
\hline 7 & 21 hari & 7215 & 65000 & 274,44 & 4,64 & 21,53 \\
\hline 8 & 21 hari & 7075 & 64000 & 270,22 & 0,42 & 0,18 \\
\hline 9 & 21 hari & 7115 & 63000 & 266,00 & $-3,80$ & 14,44 \\
\hline 10 & 21 hari & 7215 & 64000 & 270,22 & 0,42 & 0,18 \\
\hline & & & & $2.697,98$ & & 87,28 \\
\hline
\end{tabular}

$\mathrm{fu}: 21$ hari $=0,95$

$$
\begin{aligned}
& \mathrm{S}= \\
& \sqrt{\frac{\sum_{1}^{n}\left(\sigma^{1} b-\sigma^{1} b m\right)^{2}}{N-1}}=\sqrt{\frac{87,28}{9}}=3,11
\end{aligned}
$$

fb : kubus $15 \times 15 \times 15 \mathrm{~cm}=1,0$

$\sigma^{1} b=\frac{P}{A} x f u x f b$

$\sigma^{1} b k=\sigma^{1} b m-\mathrm{k} . \mathrm{s}$

$\sigma^{1} b m=\frac{\sum_{1}^{n} \sigma^{1} b}{n}=\frac{2.697,98}{10}=269,80$
$=323,26-1,92 \cdot 19,21=264,11$

$\mathrm{kg} / \mathrm{cm}$

Tabel 3.27 Hasil Test Kubus Beton $15 \times 15$ x 15 umur 21 hari (120 cc)

\begin{tabular}{|c|c|c|c|c|c|c|}
\hline No & $\begin{array}{c}\text { Umur } \\
\text { Benda } \\
\text { Uji }\end{array}$ & $\begin{array}{c}\text { Berat } \\
\text { Kering } \\
\text { Beton } \\
(\mathrm{gr})\end{array}$ & $\begin{array}{c}\text { Beban } \\
\text { Max } \\
(\mathrm{kg})\end{array}$ & $\begin{array}{c}\text { Tegangan } \\
\text { Beton }( \\
\left.\sigma^{1} b\right) \\
\left(\mathrm{kg} / \mathrm{cm}^{2}\right)\end{array}$ & $\begin{array}{c}\sigma^{1} b- \\
\sigma^{1} b m\end{array}$ & $\left(\sigma^{1} b-\sigma^{1} b m\right.$ \\
)$^{2}$
\end{tabular}


fu : 21 hari $=0,95$

\begin{tabular}{|c|c|c|c|c|c|c|}
\hline 7 & 21 hari & 7215 & 73000 & 308,22 & 4,22 & 17,81 \\
\hline 8 & 21 hari & 7050 & 71000 & 299,78 & $-4,22$ & 17,81 \\
\hline 9 & 21 hari & 7105 & 72000 & 304,00 & 0 & 0 \\
\hline 10 & 21 hari & 7355 & 73000 & 308,22 & 4,22 & 17,81 \\
\hline & & & & $3.040,00$ & & 106,86 \\
\hline
\end{tabular}

$\mathrm{fb}$ : kubus $15 \times 15 \times 15 \mathrm{~cm}=1,0$

$\sigma^{1} b=\frac{P}{A} x f u x f b$

$$
\sqrt{\frac{\sum_{1}^{n}\left(\sigma^{1} b-\sigma^{1} b m\right)^{2}}{N-1}}=\sqrt{\frac{106,86}{9}}=3,45
$$

$\sigma^{1} b m=\frac{\sum_{1}^{n} \sigma^{1} b}{n}=\frac{3.040,00}{10}=304,00$

$$
\sigma^{1} b k=\sigma^{1} b m-\mathrm{k} . \mathrm{s}
$$

$\mathrm{kg} / \mathrm{cm}$

$$
=304,00-1,83.3,45=297,69
$$

\begin{tabular}{|c|c|c|c|c|c|c|}
\hline No & $\begin{array}{l}\text { Umur } \\
\text { Benda } \\
\text { Uji }\end{array}$ & $\begin{array}{c}\text { Berat } \\
\text { Kering } \\
\text { Beton } \\
(\mathrm{gr})\end{array}$ & $\begin{array}{c}\text { Beban } \\
\text { Max } \\
(\mathrm{kg})\end{array}$ & $\begin{array}{c}\text { Tegangan } \\
\text { Beton ( } \\
\left.\sigma^{1} b\right) \\
\left(\mathrm{kg} / \mathrm{cm}^{2}\right)\end{array}$ & $\begin{array}{l}\sigma^{1} b- \\
\sigma^{1} b m\end{array}$ & $\left(\begin{array}{c}\left(\sigma^{1} b-\sigma^{1} b m\right. \\
)^{2}\end{array}\right.$ \\
\hline 1 & 21 hari & 7155 & 78000 & 329,33 & $-4,23$ & 17,89 \\
\hline 2 & 21 hari & 7210 & 79000 & 333,56 & 0 & 0 \\
\hline 3 & 21 hari & 7260 & 81000 & 342,00 & 8,44 & 71,23 \\
\hline 4 & 21 hari & 7170 & 79000 & 333,56 & 0 & 0 \\
\hline 5 & 21 hari & 7560 & 78000 & 329,33 & $-4,23$ & 17,89 \\
\hline 6 & 21 hari & 7095 & 81000 & 342,00 & 8,44 & 71,23 \\
\hline 7 & 21 hari & 7215 & 79000 & 333,56 & 0 & 0 \\
\hline 8 & 21 hari & 7050 & 78000 & 329,33 & $-4,23$ & 17,89 \\
\hline 9 & 21 hari & 7236 & 78000 & 329,33 & $-4,23$ & 17,89 \\
\hline 10 & 21 hari & 7143 & 79000 & 333,56 & 0 & 0 \\
\hline & & & & $\begin{array}{c}3.333,5 \\
6\end{array}$ & & 214,02 \\
\hline
\end{tabular}

Tabel 3.28 Hasil Test Kubus Beton $15 \times 15 \times 15$ umur 21 hari $(200 \mathrm{cc})$ 


$$
\begin{array}{ll}
\text { fu : } 21 \text { hari }=0,95 & \mathrm{~S}= \\
\mathrm{fb}: \text { kubus } 15 \times 15 \times 15 \mathrm{~cm}=1,0 & \sqrt{\frac{\sum_{1}^{n}\left(\sigma^{1} b-\sigma^{1} b m\right)^{2}}{N-1}}=\sqrt{\frac{214,02}{9}}=4,88 \\
\sigma^{1} b=\frac{P}{A} \times f u x f b & \sigma^{1} b k=\sigma^{1} b m-\mathrm{k} . \mathrm{s} \\
\sigma^{1} b m=\frac{\sum_{1}^{n} \sigma^{1} b}{n}=\frac{3.333,56}{10}=333,56 & \mathrm{~kg} / \mathrm{cm}=333,56-1,83.4,88 \quad=324,63
\end{array}
$$

Tabel 3.29 Hasil Test Kubus Beton $15 \times 15 \times 15$ umur 28 hari $(0 \mathrm{cc})$

\begin{tabular}{|c|c|c|c|c|c|c|}
\hline No & $\begin{array}{c}\text { Umur } \\
\text { Benda Uji }\end{array}$ & $\begin{array}{c}\text { Berat } \\
\text { Kering } \\
\text { Beton } \\
(\mathrm{gr})\end{array}$ & $\begin{array}{c}\text { Beban } \\
\text { Max } \\
(\mathrm{kg})\end{array}$ & $\begin{array}{c}\text { Tegangan } \\
\text { Beton }\left(\sigma^{1} b\right) \\
\left(\mathrm{kg} / \mathrm{cm}^{2}\right)\end{array}$ & $\begin{array}{c}\sigma^{1} b- \\
\sigma^{1} b m\end{array}$ & $\begin{array}{c}\left(\sigma^{1} b-\right. \\
\left.\sigma^{1} b m\right)^{2}\end{array}$ \\
\hline 1 & 28 hari & 7020 & 72000 & 320,00 & $-5,78$ & 33,41 \\
2 & 28 hari & 7230 & 73000 & 324,44 & $-1,34$ & 1,80 \\
3 & 28 hari & 7250 & 72000 & 320,00 & $-5,78$ & 33,41 \\
4 & 28 hari & 7280 & 73000 & 324,44 & $-1,34$ & 1,80 \\
5 & 28 hari & 7510 & 73000 & 324,44 & $-1,34$ & 1,80 \\
6 & 28 hari & 7100 & 74000 & 328,89 & 3,11 & 9,67 \\
7 & 28 hari & 7080 & 73000 & 324,44 & $-1,34$ & 1,80 \\
8 & 28 hari & 7085 & 73000 & 324,44 & $-1,34$ & 1,80 \\
9 & 28 hari & 7130 & 75000 & 333,33 & 7,55 & 57,00 \\
10 & 28 hari & 7150 & 75000 & 333,33 & 7,55 & 57,00 \\
\hline
\end{tabular}


Tabel 3.30 Hasil Test Kubus Beton $15 \times 15$ x 15 umur 28 hari $(80 \mathrm{cc})$

\begin{tabular}{|c|c|c|c|c|c|c|}
\hline No & $\begin{array}{c}\text { Umur } \\
\text { Benda Uji }\end{array}$ & $\begin{array}{c}\text { Kerat } \\
\text { Beton } \\
(\mathrm{gr})\end{array}$ & $\begin{array}{c}\text { Beban } \\
\text { Max } \\
(\mathrm{kg})\end{array}$ & $\begin{array}{c}\text { Teganga } \\
\mathrm{n} \text { Beton }( \\
\left.\sigma^{1} b\right) \\
\left(\mathrm{kg} / \mathrm{cm}^{2}\right)\end{array}$ & $\begin{array}{c}\sigma^{1} b- \\
\sigma^{1} b m\end{array}$ & $\begin{array}{c}\left.\sigma^{1} b m\right)^{2} \\
\sigma^{1} b-\end{array}$ \\
\hline 1 & 28 hari & 7020 & 73000 & 324,44 & $-6,23$ & 38,81 \\
3 & 28 hari & 7230 & 74000 & 328,89 & $-1,78$ & 3,17 \\
4 & 28 hari & 7150 & 75000 & 333,33 & 2,66 & 7,08 \\
5 & 28 hari & 7010 & 73000 & 324,44 & $-6,23$ & 38,81 \\
6 & 28 hari & 7200 & 75000 & 333,33 & 2,66 & 7,08 \\
7 & 28 hari & 7180 & 73000 & 324,44 & $-6,23$ & 38,81 \\
8 & 28 hari & 7085 & 7400 & 328,89 & $-1,78$ & 3,17 \\
9 & 28 hari & 7010 & 76000 & 337,78 & 7,11 & 50,55 \\
10 & 28 hari & 7105 & 75000 & 333,33 & 2,66 & 7,08 \\
\hline
\end{tabular}

fu : 28 hari $=1.00$

$\mathrm{S}=$

fb : kubus $15 \times 15 \times 15 \mathrm{~cm}=1,0$

$\sigma^{1} b=\frac{P}{A} x f u x f b$

$\sqrt{\frac{\sum_{1}^{n}\left(\sigma^{1} b-\sigma^{1} b m\right)^{2}}{N-1}}=\sqrt{\frac{245,11}{9}}=5,22$

$\sigma^{1} b m=\frac{\sum_{1}^{n} \sigma^{1} b}{n}=\frac{3.306,65}{10}=330,67$

$\sigma^{1} b k=\sigma^{1} b m-\mathrm{k} . \mathrm{s}$

$\mathrm{kg} / \mathrm{cm}$

$$
=330,67-1,83 \cdot 5,22=321,12
$$

Tabel 3.31 Hasil Test Kubus Beton $15 \times 15 \times 15$ umur 28 hari (120 cc)

\begin{tabular}{|c|c|c|c|c|c|c|}
\hline No & $\begin{array}{c}\text { Bmur } \\
\text { Benda } \\
\text { Uji }\end{array}$ & $\begin{array}{c}\text { Berat } \\
\text { Kering } \\
\text { Beton }(\mathrm{gr})\end{array}$ & $\begin{array}{c}\text { Beban } \\
\text { Max } \\
(\mathrm{kg})\end{array}$ & $\begin{array}{c}\text { Tegangan } \\
\text { Beton }\left(\sigma^{1} b\right. \\
)\left(\mathrm{kg} / \mathrm{cm}^{2}\right)\end{array}$ & $\begin{array}{c}\sigma^{1} b- \\
\sigma^{1} \mathrm{bm}\end{array}$ & $\begin{array}{c}\left(\sigma^{1} b-\right. \\
\left.\sigma^{1} \mathrm{bm}\right)^{2}\end{array}$ \\
\hline 1 & 28 hari & 7010 & 76000 & 337,78 & 4,00 & 16,00 \\
2 & 28 hari & 7230 & 74000 & 328,89 & $-4,89$ & 23,91 \\
3 & 28 hari & 7250 & 75000 & 333,33 & $-0,45$ & 0,20 \\
4 & 28 hari & 7280 & 75000 & 333,33 & $-0,45$ & 0,20 \\
5 & 28 hari & 7010 & 74000 & 328,89 & $-4,89$ & 23,91 \\
6 & 28 hari & 7150 & 76000 & 337,78 & 4,00 & 16,00 \\
\hline
\end{tabular}




\begin{tabular}{|c|c|c|c|c|c|c|}
\hline 7 & 28 hari & 7065 & 77000 & 342,22 & 8,44 & 71,23 \\
8 & 28 hari & 7085 & 75000 & 333,33 & $-0,45$ & 0,20 \\
9 & 28 hari & 7075 & 74000 & 328,89 & $-4,89$ & 23,91 \\
10 & 28 hari & 7065 & 75000 & 333,33 & $-0,45$ & 0,20 \\
\hline
\end{tabular}

fu : 28 hari $=1.00$

$$
\sqrt{\frac{\sum_{1}^{n}\left(\sigma^{1} b-\sigma^{1} b m\right)^{2}}{N-1}}=\sqrt{\frac{175,76}{9}}=4,42
$$

$\sigma^{1} b=\frac{P}{A} x f u x f b$

$$
\sigma^{1} b k=\sigma^{1} b m-\mathrm{k} . \mathrm{s}
$$

$\sigma^{1} b m=\frac{\sum_{1}^{n} \sigma^{1} b}{n}=\frac{3.337,77}{10}=333,78$ $\mathrm{kg} / \mathrm{cm}$ $=333,78-1,83 \cdot 4,42=325,69$

Tabel 3.32 Hasil Test Kubus Beton $15 \times 15 \times 15$ umur 28 hari $(200 \mathrm{cc})$

\begin{tabular}{|c|c|c|c|c|c|c|}
\hline No & $\begin{array}{c}\text { Umur } \\
\text { Benda } \\
\text { Uji }\end{array}$ & $\begin{array}{c}\text { Berat } \\
\text { Kering } \\
\text { Beton } \\
(\mathrm{gr})\end{array}$ & $\begin{array}{c}\text { Beban } \\
\text { Max }(\mathrm{kg})\end{array}$ & $\begin{array}{c}\text { Tegangan } \\
\text { Beton }( \\
\left.\sigma^{1} b\right) \\
\left(\mathrm{kg} / \mathrm{cm}^{2}\right)\end{array}$ & $\begin{array}{c}\sigma^{1} b- \\
\sigma^{1} b m\end{array}$ & $\begin{array}{c}\left(\sigma^{1} b-\right. \\
\left.\sigma^{1} \mathrm{bm}\right)^{2}\end{array}$ \\
\hline 1 & 28 hari & 7115 & 82000 & 364,44 & 6,22 & 38,69 \\
3 & 28 hari & 7210 & 82000 & 364,44 & 6,22 & 38,69 \\
4 & 28 hari & 7250 & 80000 & 355,56 & $-2,66$ & 7,08 \\
5 & 28 hari & 7230 & 79000 & 351,11 & $-7,11$ & 50,55 \\
6 & 28 hari & 7150 & 79000 & 351,11 & $-7,11$ & 50,55 \\
7 & 28 hari & 7080 & 80000 & 355,56 & $-2,66$ & 7,08 \\
8 & 28 hari & 7085 & 82000 & 364,44 & 6,22 & 38,69 \\
9 & 28 hari & 7045 & 80000 & 355,56 & $-2,66$ & 7,08 \\
10 & 28 hari & 7025 & 81000 & 360,00 & 1,78 & 3,17 \\
\hline
\end{tabular}


fu : 28 hari $=1.00$

$\mathrm{fb}$ : kubus $15 \times 15 \times 15 \mathrm{~cm}=1,0$

$\sigma^{1} b=\frac{P}{A} x f u x f b$

$\sigma^{1} b m=\frac{\sum_{1}^{n} \sigma^{1} b}{n}=\frac{3.582,22}{10}=244,75$
$\mathrm{S}=$

$$
\begin{aligned}
& \sqrt{\frac{\sum_{1}^{n}\left(\sigma^{1} b-\sigma^{1} b m\right)^{2}}{N-1}}=\sqrt{\frac{244,75}{9}}=5,21 \\
& \sigma^{1} b k=\sigma^{1} b m-\mathrm{k} . \mathrm{s} \\
& \mathrm{kg} / \mathrm{cm}
\end{aligned}
$$

\begin{tabular}{|c|c|c|c|c|c|}
\hline \multirow{2}{*}{$\begin{array}{l}\text { Umur } \\
\text { Beton }\end{array}$} & \multirow{2}{*}{$\begin{array}{l}\text { Kuat } \\
\text { Tekan } \\
\text { Beton }\end{array}$} & \multicolumn{4}{|c|}{ PENAMBAHAN ADDITON H.E } \\
\hline & & $0 \mathrm{cc}$ & $80 \mathrm{cc}$ & $120 \mathrm{cc}$ & $200 \mathrm{CC}$ \\
\hline \multirow[t]{3}{*}{7 Hari } & $\left(\mathrm{Kg} / \mathrm{Cm}^{2}\right)$ & 139,02 & 146,61 & 159,63 & 178,95 \\
\hline & ( Hari) & 7,00 & 7,38 & 8,04 & 9,01 \\
\hline & $(\%)$ & 0 & 5,46 & 14,83 & 28,72 \\
\hline \multirow[t]{3}{*}{14 Hari } & $\left(\mathrm{Kg} / \mathrm{Cm}^{2}\right)$ & 222,06 & 224,18 & 234,46 & 248,22 \\
\hline & (Hari) & 14 & 14,13 & 14,78 & 15,65 \\
\hline & (\%) & 0 & 0.90 & 5,53 & 11,72 \\
\hline \multirow[t]{3}{*}{21 Hari } & $\left(\mathrm{Kg} / \mathrm{Cm}^{2}\right)$ & 231,84 & 264,11 & 297,69 & 324,63 \\
\hline & (Hari) & 21 & 23,92 & 26,96 & 29,40 \\
\hline & $(\%)$ & 0 & 13,92 & 28,40 & 40,02 \\
\hline \multirow[t]{3}{*}{28 Hari } & $\left(\mathrm{Kg} / \mathrm{Cm}^{2}\right)$ & 317,16 & 321,12 & 325,69 & 348,69 \\
\hline & (Hari) & 28 & 28,35 & 28,75 & 30,78 \\
\hline & $(\%)$ & 0 & 1,25 & 2,69 & 9,94 \\
\hline
\end{tabular}

Tabel 3.33. Kuat Tekan Beton Umur 7, 14, 21 dan 28 Hari, Dengan Penambahan Additon H.E (0 cc, 80 cc, 120 cc Dan 200 cc)

Dari Tabel 3.33 diketahui hal-hal sebagai berikut :

1. Hasil Penelitian menunjukkan bahwa pada umur beton 7 hari dengan penambahan bahan tambahan (Additive) Addditon H.E menyebabkan:

Penambahan Additon H.E dengan dosis $80 \mathrm{cc}$, menyebabkan percepatan kuat tekan beton dari umur 7 hari setara dengan beton biasa umur 7,38 hari dan menyebabkan peningkatan terhadap kuat tekan beton sebesar $5,46 \%$ tetapi hasil yang diperoleh tidak sesuai dengan yang telah tercantum dalam brosur prodak Additon H.E yaitu dengan menggunakan dosis 80 cc kekuatan tekan beton umur 10 hari setara dengan beton biasa umur 28 hari.

- Penambahan Additon H.E dengan dosis 120 cc, menyebabkan percepatan kuat tekan beton dari umur 7 hari setara dengan beton biasa umur 8,04 hari dan menyebabkan peningkatan terhadap kuat tekan beton sebesar 
$14,83 \%$ tetapi hasil yang diperoleh tidak sesuai dengan yang telah tercantum dalam brosur prodak Additon H.E yaitu dengan menggunakan dosis 120 cc kekuatan tekan beton umur 7 hari setara dengan beton biasa umur 28 hari.

- Penambahan Additon H.E dengan dosis 200 cc, menyebabkan percepatan kuat tekan beton dari umur 7 hari setara dengan beton biasa umur 9,01 hari dan menyebabkan peningkatan terhadap kuat tekan beton sebesar $28,72 \%$ tetapi hasil yang diperoleh tidak sesuai dengan yang telah tercantum dalam brosur prodak Additon H.E yaitu dengan menggunakan dosis 200 cc kekuatan tekan beton umur 5 hari setara dengan beton biasa umur 28 hari.

2. Pada umur beton 14 hari dengan penambahan bahan tambahan (Additive) Additon H.E menyebabkan:

- Penambahan Additon H.E dengan dosis $80 \mathrm{cc}$, menyebabkan percepatan kuat tekan beton dari umur 14 hari setara dengan beton biasa umur 14,13 hari dan menyebabkan peningkatan terhadap kuat tekan beton sebesar $0,90 \%$

- Penambahan Additon H.E dengan dosis $120 \mathrm{cc}$, menyebabkan percepatan kuat tekan beton dari umur 14 hari setara dengan beton biasa umur 14,78 hari dan menyebabkan peningkatan terhadap kuat tekan beton sebesar $5,53 \%$

- Penambahan Additon H.E dengan dosis 200 cc, menyebabkan percepatan kuat tekan beton dari umur 14 hari setara dengan beton biasa umur 15,65 hari dan menyebabkan peningkatan terhadap kuat tekan beton sebesar $11,72 \%$

3. Pada umur beton 21 hari dengan penambahan bahan tambahan Additive Addditon H.E menyebabkan:

- Penambahan Additon H.E dengan dosis $80 \mathrm{cc}$, menyebabkan percepatan kuat tekan beton dari umur 21 hari setara dengan beton biasa umur 23,92 hari dan menyebabkan peningkatan terhadap kuat tekan beton sebesar $13,92 \%$

- Penambahan Additon H.E dengan dosis 120 cc, menyebabkan percepatan kuat tekan beton dari umur 21 hari setara dengan beton biasa umur 26,96 hari dan menyebabkan peningkatan terhadap kuat tekan beton sebesar $28,40 \%$

- Penambahan Additon H.E dengan dosis 200 cc, menyebabkan percepatan kuat tekan beton dari umur 21 hari setara dengan beton biasa umur 29,40 hari dan menyebabkan peningkatan terhadap kuat tekan beton sebesar $40,02 \%$

4. Pada umur beton 28 hari dengan penambahan bahan tambahan (Additive) Additon H.E menyebabkan:

Penambahan Additon H.E dengan dosis 80 cc, menyebabkan percepatan kuat tekan beton dari umur 28 hari setara dengan beton biasa umur 28,35 hari dan menyebabkan peningkatan terhadap kuat tekan beton sebesar $1,25 \%$

- Penambahan Additon H.E dengan dosis 120 cc, menyebabkan percepatan kuat tekan beton dari umur 28 hari setara dengan beton biasa umur 28,75 hari dan menyebabkan peningkatan terhadap kuat tekan beton sebesar $2,69 \%$

- Penambahan Additon H.E dengan dosis 200 cc, menyebabkan percepatan kuat tekan beton dari umur 28 hari setara dengan beton biasa umur 30,78 hari dan menyebabkan peningkatan terhadap kuat tekan beton sebesar $9,94 \%$

Berbagai penelitian telah dilakukan untuk mendapatkan alternative lain bahan dasar dari beton untuk dapat meningkatkan mutu beton diantaranya yaitu dengan jalan mengurangi atau menambahkan bahan tambahan tertentu untuk mendapatkan mutu beton yang lebih baik, seperti yang dilakukan oleh Wibawa Sastra, I Made. 2004. Penelitian Penggunaan Pecahan Genteng Pejaten Sebagai Pengganti Agregat Kasar Dalam Campuran Beton 
Meningkatkan Kuat Tekan Karakteristik Beton. Denpasar: Fakultas Teknik Universitas Mahasaraswati. Begitu juga penelitian yang dilakukan oleh Imaculata Maria G.M. 2009. Penelitian Penambahan Serbuk Batu Tabas Karangasem Dalam Mengatasi Pengaruh Magnesium Klorida Pada Campuran Beton. Denpasar: Tugas Akhir Universitas Mahasaraswati.

Beberapa penelitian terdahulu menunjukan bahwa penambahan bahan tambahan kimia dapat meningkatkan secara signifikan kuat tekan beton. Seperti yang telah dilakukan oleh Harianto, Setijadi. M,N., 2005. Dalam penelitiannya menggunakan penambahan Simultan Sika Viscocrete (SV) dan Sikament-520 (S-520) pada prosentase tertetu dapat meningkatkan kuat tekan beton. Sebenarnya masih ada tipe additiveadditive lain yang dapat meningkatkan secara signifikan kuat tekan beton, tapi pemanfaatannya sendiri untuk industri readymix di Indonesia belum maksimal. Additive-additive yang maksud yaitu: VMA (viscosity-modifying admixtures), SRA (shrinkage reducing admixture) dan AWA (anti washout agent). (Teknologi Additive dan Admixture).

\section{Simpulan dan Saran}

\subsection{Simpulan}

Tabel 3.1. Kuat Tekan Beton Umur 7, 14, 21 dan 28 Hari, Dengan Penambahan Additon H.E (0 cc, 80 cc, 120 cc Dan 200 cc)

\begin{tabular}{|l|c|c|c|c|c|}
\hline \multirow{2}{*}{$\begin{array}{l}\text { Umur } \\
\text { Beton }\end{array}$} & $\begin{array}{c}\text { Kuat Tekan } \\
\text { Beton }\end{array}$ & \multicolumn{4}{|c|}{ PENAMBAHAN ADDITON H.E } \\
\cline { 3 - 6 } & & $0 \mathrm{cc}$ & $80 \mathrm{cc}$ & $120 \mathrm{cc}$ & $200 \mathrm{CC}$ \\
\hline 7 Hari & $\left(\mathrm{Kg} / \mathrm{Cm}^{2}\right)$ & 139,02 & 146,61 & 159,63 & 178,95 \\
& $($ Hari) & 7,00 & 7,38 & 8,04 & 9,01 \\
& $(\%)$ & 0 & 5,46 & 14,83 & 28,72 \\
\hline 14 Hari & $\left(\mathrm{Kg} / \mathrm{Cm}^{2}\right)$ & 222,06 & 224,18 & 234,46 & 248,22 \\
& $($ Hari $)$ & 14 & 14,13 & 14,78 & 15,65 \\
& $(\%)$ & 0 & 0.90 & 5,53 & 11,72 \\
\hline 21 Hari & $\left(\mathrm{Kg} / \mathrm{Cm}^{2}\right)$ & 231,84 & 264,11 & 297,69 & 324,63 \\
& $($ Hari $)$ & 21 & 23,92 & 26,96 & 29,40 \\
& $(\%)$ & 0 & 13,92 & 28,40 & 40,02 \\
\hline 28 Hari & $\left(\mathrm{Kg} / \mathrm{Cm}^{2}\right)$ & 317,16 & 321,12 & 325,69 & 348,69 \\
& $($ Hari $)$ & 28 & 28,35 & 28,75 & 30,78 \\
& $(\%)$ & 0 & 1,25 & 2,69 & 9,94 \\
& & & &
\end{tabular}

Dari hasil penelitian kuat tekan beton dengan penambahan bahan tambahan (additive) Additon H.E dapat diambil beberapa kesimpulan sebagai berikut:

- Setelah dilaksanakan test kuat tekan kubus beton dan analisa kuat tekan beton dari 10 benda uji, dimana pada masing-masing percobaan dilaksanakan pembuatan benda uji kubus dengan penambahan Additon H.E dengan dosis $80 \mathrm{cc}, 120 \mathrm{cc}$, dan 200 cc dapat mempercepat dan 
meningkatkan Kuat Tekan Karakteristik Beton.

- Setelah dilaksanakan test kubus beton dengan umur 7,14,21 dan 28 hari diperoleh hasil kuat tekan beton sebagai berikut:

\subsection{Saran}

Saran yang dapat dikemukakan sehubungan dengan penelitian ini adalah sebagai berikut:

1. Perlu diadakan penelitian lanjutan pada penambahan bahan tambahan (additive) addition H.E. dalam dosis tertentu untuk memperoleh percepatan waktu pengerasan yang lebih cepat dan kuat tekan karakteristik beton yang maksimal.

2. Untuk mendapatkan hasil yang lebih baik agar digunakan benda uji yang lebih banyak atau sesuai persyaratan $\mathrm{PBI}, 71$ untuk masingmasing campuran beton.

\section{DAFTAR PUSTAKA}

Budhi Saputro, A., 2008. Penelitian Kuat tekan dan kuat tarik beton mutu tinggi dengan Fly Ash sebagai bahan pengganti sebagian semen dengan kuat tekan $45 \mathrm{MPa}$. Yogyakarta: Fakultas Teknik Sipil Dan Perencanaan Universitas Islam Indonesia. http://www.scribd.com/doc/3745749 5/Kuat-Tekan-Dan-Kuat-TarikBeton. Donwnload, 10-10-2010.

Departemen Pekerjaan Umum. LPMB. Tata Cara Rencana Pembuatan Campuran Beton Normal. SK SNI T-15-1990-03. Cetakan Pertama,

DPU - Yayasan LPMB , 1991. Bandung
Harianto, Setijadi. M,N., 2005. Pengaruh penambahan Simultan Sika Viscocrete-Sikament-520 Pada Beton PPC-AKB Ditinjau Terhadap Kuat Tekan.Yogyakarta: Hasil Penelitian Universitas Janabadra.

Imaculata Maria G.M. 2009. Penelitian Penambahan Serbuk Batu Tabas Karangasem Dalam Mengatasi Pengaruh Magnesium Klorida Pada Campuran Beton. Denpasar: Tugas Akhir Universitas Mahasaraswati.

Mulyono. T., 2003. Teknologi Beton. Andi: Jakarta

Subakti. A., 1994. Teknologi Beton Dalam Praktek. Jurusan Teknik Sipil FTSP. Institut teknologi sepuluh November Surabaya. Surabaya

Teknologi Additivedan Admixture. 2008. Type - type additive yang ada di Industri Indonssia. http://sasonov.wordpress.com/2008 102/02/teknologi-additive-danadmixture/. Donwnload, 10-102010.

Wangsadinata. W., 1971. Peraturan beton Bertulang Indonesia N.I - 2. Bandung: Direktorat Penyelidikan Masalah Bangunan Direktorat Jenderal Cipta Karya Departemen Pekerjaan Umum dan Tenaga Listrik.

Wibawa Sastra, I Made. 2004. Penelitian Penggunaan Pecahan Genteng Pejaten Sebagai Pengganti Agregat Kasar Dalam Campuran Beton Meningkatkan Kuat Tekan Karakteristik Beton. Denpasar: Fakultas Teknik Universitas Mahasaraswati. 